\title{
Fra fæstningsby til Øresundsmetropol
}

\author{
Af Henning Bro
}

Som afsæt til videre forskning i hovedstads- og øresundsområdets regionale historie sætter denne artikel fokus på, hvorledes Nordøstsjælland i store træk udvikle sig til en af landets mest integrerede regioner. Således de lange linjer fra middelalderens sundbyer, over enevældens total dominerende hovedstad, til dannelsen af hovedstadsmetropolen op gennem det 20. århundrede og dennes begyndende sammensmeltning med byer og landskaber øst for Øresund efter årtusindeskiftet.

\section{Fæstningsbyen og dens opland - tiden før 1850}

Fra vikingetiden og op gennem middelalderen udvikledes det danske bysystem først i form af selvgroede og senere kongeanlagte indlandsbyer og siden kongeanlagte kystbyer i 1100- og 1200tallet og i den sidste del af perioden. Byerne blev tidligt omfattet af kongemagtens interesse og udskilt som særlige administrations- og skatteområder direkte under kronen, der yderligere øgede indtægterne fra byerne ved senere tildeling af købstadsprivilegier: En vis form for bymæssigt selvstyre, egen jurisdiktion og eneret til handel og håndværk i en radius af 1-4 mil. Oveni dette vækstgrundlag kom så de rigdomme, som kirkemagten samlede omkring købstædernes kirker og klostre, og den administration af by og opland, som udgik fra de kronborge, som en betydelig del af byerne lå i ly af, og som her ydede yderligere beskyttelse ud over den, som eventuelle bymure, palisadeværker og voldegrave gav.

Købstæderne blev bundet sammen i et system og det centrale omdrejningspunkt i den feudale $\emptyset$ konomi i form af: Formidling af varestrømme mellem by og opland, administrative og kulturelle serviceydelser til oplandet og modtagelse og videregivelse af varer og tilsvarende ydelser til og fra andre og større købstæder. Det største antal købstæder nåedes i det daværende Danmark i starten af 1500-tallet med 115 byer, og af landets 81 købstadskommuner før kommunalreformen i 1970 havde ikke mindre end 76 middelalderlige rødder.

\section{København}

Trods arkæologisk evidens for en tidligere datering, er Københavns grundlæggelse traditionelt blevet dateret til året 1167, hvor Valdemar den Store overdrog landsbyen Havn og andre omkringliggende landsbyer til biskop Absalon og dermed Roskilde Bispestol. Kort efter opførte Absalon en ringmursborg, som gav stedet, som naturhavn mellem Sjælland og Amager, så meget beskyttelse, at Havn udviklede sig til en købstad, København, der dermed kom til at tilhøre den gruppe af kystbyer, som kronen og i enkelte tilfælde også kirkemagten anlagde og udviklede i det 12. og 13. århundrede.

Hverken i størrelse eller med hensyn til erhvervsgrundlag, rettigheder eller beføjelser adskilte København sig i den første tid fra de $\varnothing$ vrige danske købstæder. I løbet af 1200 -tallet voksede byen sig større, fik købstadsstatus 1254 og rykkede op blandt landets store byer, der fungerede som hovedporte for varestrømme i det danske bysystem og i forhold til udlandet. Da kongen, det beskedne hof og den lille centraladministration rejste fra by til by eller fra borg til borg, bevirkede det, i modsætning til bl.a. England og Frankrig men i lighed med de øvrige nordiske lande, at der i Danmark i middelalderen ikke udvikledes købstæder, der i størrelse, myndighed og erhverv adskilte sig markant fra hinanden. 
I 1416 overgik staden København og de $\varnothing$ vrige jorder i oplandet, der hørte direkte under borgens myndighed, fra kirken til kronen, og med rejsekongedømmets gradvise afvikling op gennem den sidste del af middelalderen tog konge, hof og administration i stadig større omfang fast ophold i byen. At København efterhånden blev rigets hovedstad, førte dog ikke i første omgang til, at byen størrelsesmæssigt kom til at adskille sig markant fra landets $\emptyset$ vrige købstæder. I forhold til købstædernes fortsat meget begrænsede befolkningstal i den første del af 1500-tallet var København godt nok blevet landets største med 4.500 indbyggere, men blev tæt fulgt af Ribe og Århus med hver med en befolkning på 4.200 og Malmø og Helsingør med hver 3.400 og 1700 indbyggere.

Tabel 1. Danmarks ti største byer, 1672 og 1855

\begin{tabular}{|c|c|l|c|}
\hline \multicolumn{2}{|c|}{1672} & \multicolumn{2}{c|}{1855} \\
\hline København & 41.000 & København & 143.591 \\
\hline Allborg & 4.181 & Odense & 12.932 \\
\hline Helsing $\varnothing \mathrm{r}$ & 4.033 & Alborg & 9.102 \\
\hline Odense & 3.808 & Helsingør & 9.097 \\
\hline Arhus & 3.474 & Arhus & 8.891 \\
\hline Viborg & 2.704 & Randers & 8.844 \\
\hline Roskilde & 2.196 & Haderslev & 7.477 \\
\hline Randers & 2.036 & Horsens & 7.250 \\
\hline Ribe & 1.939 & Fredericia & 5.579 \\
\hline Nakskov & 1.920 & Svendborg & 5.280 \\
\hline
\end{tabular}

Kilde: www.byhistorie.dk/den-klassiske-periode

Handelsopsvinget op gennem resten af 1500-tallet og ind i det nye århundrede gavnede hele det danske bysystem og i særlig grad København, men byens særstilling slog først for alvor igennem med den tidlige merkantilistiske erhvervspolitik i den første halvdel af 1600-tallet, den samtidigt styrkede kongemagt og dens centraladministrative oprustning i hovedstaden. Samtidig med de nye byer, som kronen anlagde i Slesvig-Holsten, i landskaberne øst for Øresund og i Norge, og udvidelser og befæstning af nogle af de eksisterede købstæder, igangsattes en omfattende udvidelse og nybefæstning i form af bastionære anlæg af København. Først Christianshavn og siden Nykøbenhavn $\varnothing$ st for den gamle middelalderby.

Med enevældens forstærkede administrative opbygning efter 1660, de militære tyngdepunkter Holmen og Kastellet, de samtidige merkantilistiske erhvervsinitiativer, i form af en oprustning af manufakturer og handelskompagnier, og den vækst, som dermed genereredes i byen, blev

København landets eneste storby og uden sammenligning landets største by. Allerede i 1672 havde København med 41.000 indbyggere indtaget denne position, og var 10 gange så stor som landets næststørste købstæder, Ålborg. Og dynamikken fortsatte op gennem resten af århundredet, i 1700tallet og videre ind i det følgende århundrede.

I kraft af den særstilling hovedstaden opnåede, opstod et såkaldt primatbysystem med København som centrum for det danske imperium med Danmark, Slesvig-Holsten, Norge, de nordatlantiske besiddelser og tropekolonierne og som den helt dominerende by i forhold til et stort antal langt mindre købstæder, hvis folketal stagnerede, og hvis erhvervsgrundlag for det meste var blevet reduceret til vareproduktion for og handel med det nære opland. ${ }^{1}$ De gentagne krige med Sverige, der fulgte med kampen om den regionale magt i Norden og Nordeuropa, og tabet af de østdanske landskaber op gennem 1600-tallet var afgørende for krisen i provinsens købstæder. Samtidig skete enevældens magtbaseopbygning i og merkantilismens koncentration af udenlands-og kolonihandel, tidlig industriel virksomhed og øvrig ressourceoverførsel til København på bekostning af provinsens købstæder. 
Med den forøgede handel og skibsfart i den sidste del af 1700-tallet gik særligt provinsens havnebyer på ny ind i en længere periode med fremgang. Tendensen underst $\varnothing$ ttedes af landboreformernes opløsning af landbrugssamfundets feudaløkonomi, der igangsattes på samme tid og fortsatte ind i det nye århundrede, hvor det skabte forudsætningen for en udvidet korneksport med de afledte virkninger, som det fik for købstædernes økonomi. Væksten førte til en markant ændring i den størrelsesmæssige rangordning blandt landets 10 største købstæder (tabel 1). Byer som Odense, Ålborg, Århus og Randers befæstede deres position med fra en fordobling til en firedobling af folketallet fra 1672 til nogle år efter enevældens fald, mens helt nye byer med endnu større vækstrater rykkede op blandt byernes topti.

Selv om Københavns folketal i samme periode "kun" mere end tredobledes, og dermed lå under nogle af provinsbyernes tilsvarende befolkningstilvækst, førte væksten i byøkonomien under senenevælden til, at København kunne befæste sin totaldominerende position som centralby i det danske primatbysystem. Mens Københavns folketal i 1672 "kun" var 10 gange større end den næstst $\varnothing$ rste købstads og udgjorde 61 procent af folketallet i landets ti største byer, var hovedstaden i midten af det 19. århundrede, med 130.000 indbyggere, blevet tolv gange større end den næstst $\varnothing$ rste by, Odense. Et volumen medførte, at København på dette tidspunkt rummede 12 procent af landets befolkning og 45 procent af dets bybefolkning og lagde beslag på to tredjedel af det samlede folketal i byernes topti. ${ }^{2}$

\section{Hovedstadsoplandet}

Ligesom København overgik de nærmest liggende landsbyer og senere hovedparten af det senere Københavns Amt fra kronen til kirkemagten i den første del af middelalderen. Sammen med byen førtes det nærmeste opland tilbage til kronen i 1416 for at blive underlagt Københavns Len og dermed ikke staden København, og ved reformationen i 1536 fulgte resten af kirkegodset, der tillige tillagdes Københavns Len. Op igennem middelalderen var samspillet mellem København og oplandets fæstebønder nok ikke anderledes end andre steder i landet, men her udvidedes dog gradvist stadens uden for liggende byjord. Københavns udenbys marker var således nået frem til søerne, og i slutningen af middelalderen afvikledes to af de tre nærmeste landsbyer, hvis jorder blev en del af stadens grund, hvor senere brokvarterene opstod. Kun landsbyen Solbjerg, hvis landsbymark omfattede hovedparten af det senere Frederiksberg, gik fri og fortsatte under Københavns Len og Sokkelund Herred.

Med kronens og senere enevældens magtopbygning i hovedstaden, kom København allerede fra starten af 1600-tallet til at øve en langt større indvirkning på udviklingen i oplandet, end det blev tilfældet i andre af landets købstadsoplande. Allerede 1621 nedlagdes landsbyen Solbjerg, og fæstebønderne flyttedes til fæstegårde i andre landsbyer på oplandets krongods. Bymarken og tillagte arealer, svarende til Frederiksbergs senere udstrækning, udlagdes derefter til ladegårdsmark for den ladegård, der opførtes ved det nuværende Radiohuset, og som kom til at sortere under Københavns Slot som hovedgård. Selve ladegården blev tidens største og mest moderne avlsgård og integreredes i det ydre fæstningsanlæg, der lagdes uden om København i forbindelse med byens udvidelse og nybefæstning. Ladegården skulle opsamle landgildeydelser fra oplandets kronbønder, hvoraf nogle samtidig som hoveri skulle varetage markarbejdet på ladegårdsmarken, hvis produktion reserveredes slottets hofhusholdning. Som følge af den særlige hoveribyrde, der lå på kornbønderne i hovedstadens opland, så som vejvedligeholdelse og kørsel for kronen, blev rømning fra markarbejdet på ladegårdsmarken så omfattende, at den traditionelle hovedgårdsdrift måtte opgives. I stedet bortfæstedes ladegårdsmarken 1651 til 20 overtallige bønder fra St. Magleby på 
Amager. De anlagde lige øst for det gamle Solbjerg den nye landsby Ny Amager, langs Frederiksbergs senere Allégade, og for at sikre leverancerne til hofhusholdningen, som en art landgilde, begunstigede bønderne på flere områder: Kirkeret, frihed for hoveri og andre kongelige afgifter samt et ganske udstrakt sognestyre.

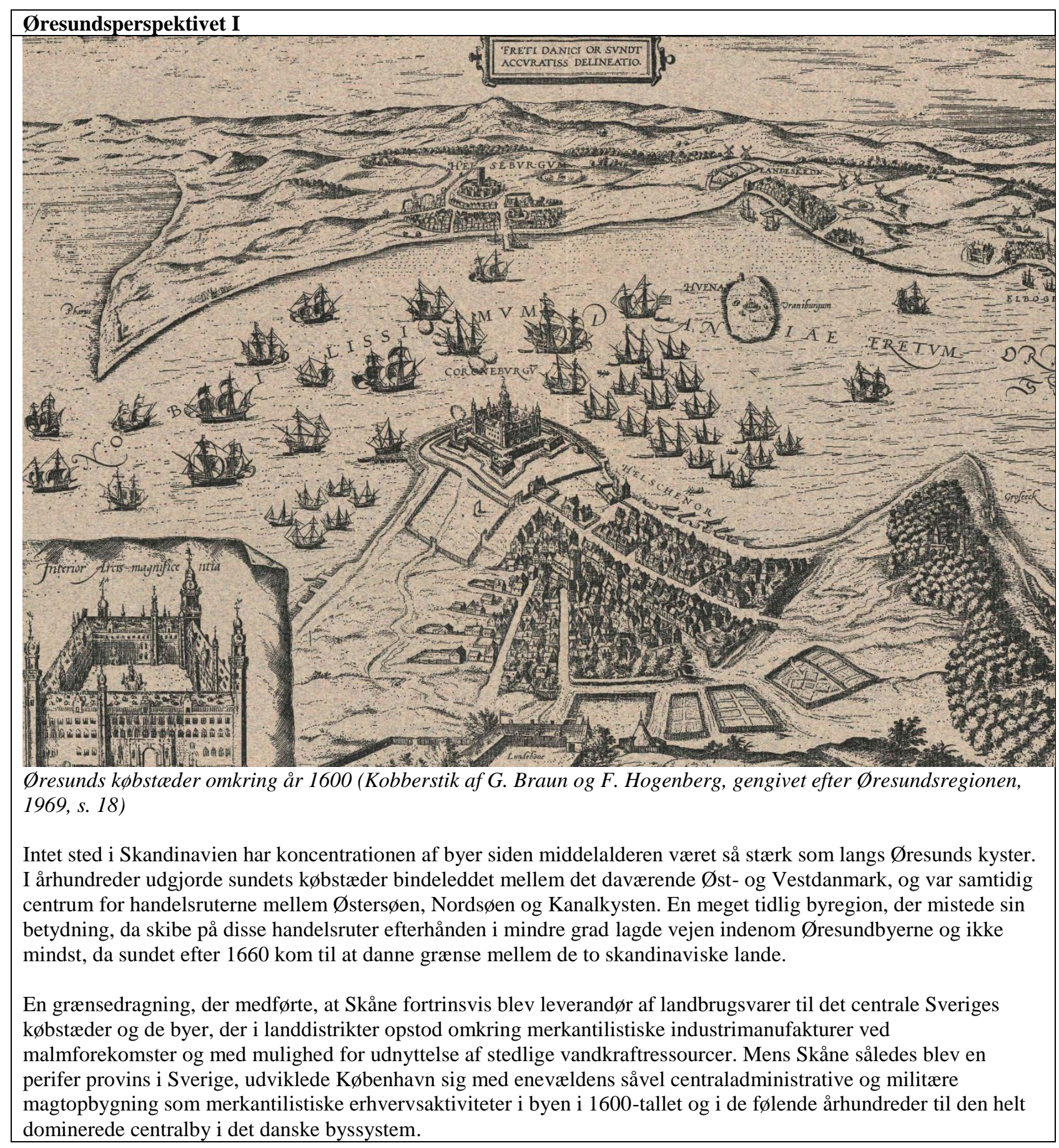

Trods særstillingen blev vilkårene stadig vanskeligere for Ny Amager op gennem den sidste halvdel af 1600-tallet. Allerede under Københavns svenske belejring i 1658 blev by og mark ødelagt. I 60’erne gjorde kronen det første indhug i bymarken, da den sydligste gård blev inddraget til lystgård for kongefamiliens næste generation, og 10 år efter blev et større areal udlagt til falkoneri til opdræt af islandske og norske falke til hoffets eget brug eller som gaver til fremmede fyrstehuse. 
Bymarken gav samtidig utilstrækkeligt udbytte, og da afgifterne blev sat op som følge af enevældshoffets vækst, kom bønderne bagud med afgifterne. Da de for at klare skærene ulovligt frasolgte en mindre del af jorden til københavnere, der ønskede udenbys grunde, blev forholdet til kronen så belastet, at den efter landsbyens nedbrænding i 1697 inddrog hele bymarken. Hovedparten blev derefter udlagt som hømark for de kongelige stalde i København, mens et stort område vest for landsbyen udlagdes til slotshaver i tilknytning til enevældens sommerresidensslot, Frederiksberg, som Frederik IV og de efterfølgende konger lod opføre og udbygge på toppen af områdets højderyg i årene mellem 1699 og 1738. Fra den krogede middelalderlige Roskildevej, som Vesterbrogade var, førtes den brede boulevard, Frederiksberg Alle, 1703 som en anden Avenue de Pais frem til det danske Versailles.

Også længere ude i oplandet kom hoffet i hovedstaden til at øve sin indvirkning. Ved nedlæggelse af en hel landsby i Lyngby Sogn og inddragelse af yderligere arealer skabtes allerede i 1670 Jægersborg Dyrehave og Hegn som store indhegnede områder for den kongelige jagt, og på højdedraget med udsigt over Øresund opførtes jagtslottet Eremitagen 1736. Tilsvarende anlagdes nye skove med jagtlinjer, bl.a. Hareskovene, til parforcejagt, ligesom området nord for Vejle $\AA$ udlagdes til kongelig vildtbane. Længere oppe i Nordsjælland var kirkegodset ved reformationen overgået til kronen, der op gennem resten af 1500-tallet ved mageskifter sikrede, at det meste af Frederiksborg Amt blev kongeligt gods. De ældre kongelige herregårde, der her lå nærmest hovedstaden, blev til nye land- og jagtslotte: Frederiksborg allerede lige efter år 1600, Hirschholm i $1720^{\prime}$ erne og i samme årti kom det nye anlæg Fredensborg til.

Da de gamle selvgroede, ofte middelalderlige, vejes tilstand var problematisk, anlagde kronen fra omkring år 1600 en række nye kongeveje fra hovedstaden og frem til de forskellige slotsanlæg og til en generel ophjælpning af erhvervslivet. Omkring år 1600 på strækningerne frem til Frederiksborg-Helsingør og Roskilde-Ringsted. På strækningen over Hømarken, nuværende Gl. Kongevej-Peter Bangs Vej, afløstes lige efter år 1700 sidstnævnte kongevej af den nye kongevej, der vest for Frederiksberg Slot førte slotsalleen, Frederiksberg Allé, videre for at slutte den til Roskildevejen ved Damhussøen. Gennem den sidste halvdel af 1700-tallet anlagde enevældsstaten, under ledelse af den indkaldte franske vejingeniør Jean Marmillod, et nyt system af hovedveje som chausséer, der fulgte lige linjer mellem de destinationer, som vejene skulle passere: Den omlagte kongevej København-Fredensborg og den nyanlagte København-Roskilde med videre forbindelse ud på Sjælland til Kalundborg og Køge-Vordingborg.

Ikke kun for hoffet fik hovedstadsoplandet betydning for rekreation og adspredelse. Mens adelsfolk, der havde gårde i København, om sommeren tog til hovedgårdene på provinsens godser, søgte hovedstadens højere borgerskab ud til gårde, som opkøbtes eller blev lejet uden for byen. Fra slutningen af 1600-tallet og gennem de følgende 150 år blev det stadig mere almindeligt, at medlemmer af kongefamilien, industrialister, stork øbmænd, statens $\varnothing$ verste embedsmænd og godsejere med palæer i København opførte egentlige landsteder i oplandet: Prægtigt og st $\varnothing$ rst de regulære slotskomplekser som Bernstorff (1767), Charlottenlund (1717) og Sorgenfri (1702), men også et stort antal palælignende mindre landsteder med eller uden tilhørende landbrug. Nogle i de sø- og kystnære naturskønne omgivelser i den nordlige del af Gladsaxe Sogn og ellers i Gentofte, Lyngby og Søllerød sogne. Andre tæt ved enevældens sommerresidens Frederiksberg: I landsbyen Ny Amager, langs slotsalleen og på hele den nordlige halvdel af Hømarken, som kronen satte på auktion i 1765. 
En del af Københavnsegnens landliggere havde genereret deres formuer på grundlag af 1600-og 1700-tallets $\varnothing$ konomiske politik: merkantilismen. Den havde til formål gennem statsstøtte, monopoler og andre privilegier at fremme import af råvarer og indenlandsk produktion, at fremskaffe varer til eksport og at undgå indførsel af fremmede varer. Som hovedstad og centralby i det danske byprimatsystem blev København hjemsted for hovedparten af de merkantilistiske virksomheder: Handelskompagnier til oversøisk handel og industrimanufakturer, der i hovedsagen placeredes inde i byen bag voldene. Hvor forsyning med vand til kraft eller selve produktionen eller andre forhold krævede det, lagdes de ofte mere arealkrævende fabriksanlæg ude i

hovedstadsoplandet: Lige uden for byen i 1700-tallet flere tekstilmanufakturer og kattuntrykkerier på Blegdammen, på Hømarken anlægget på Vodroffsgård til klæde- og senere sejldugsproduktion samt teglværket og fajancefabrikken Kastrup Værk på Amager. Langs Mølleåen en stribe af manufakturer med tilhørende små bysamfund i 1600- og 1700-tallet og længere mod nord, Usserød og Brønsholmdals klædefabrikker fra slutningen af det 18. århundrede, Hammermøllen og siden geværfabrikken ved Hellebæk med rødder tilbage til starten af 1600-tallet og endelig Frederiks Værk ved Roskilde Fjord fra midten af 1700-tallet.

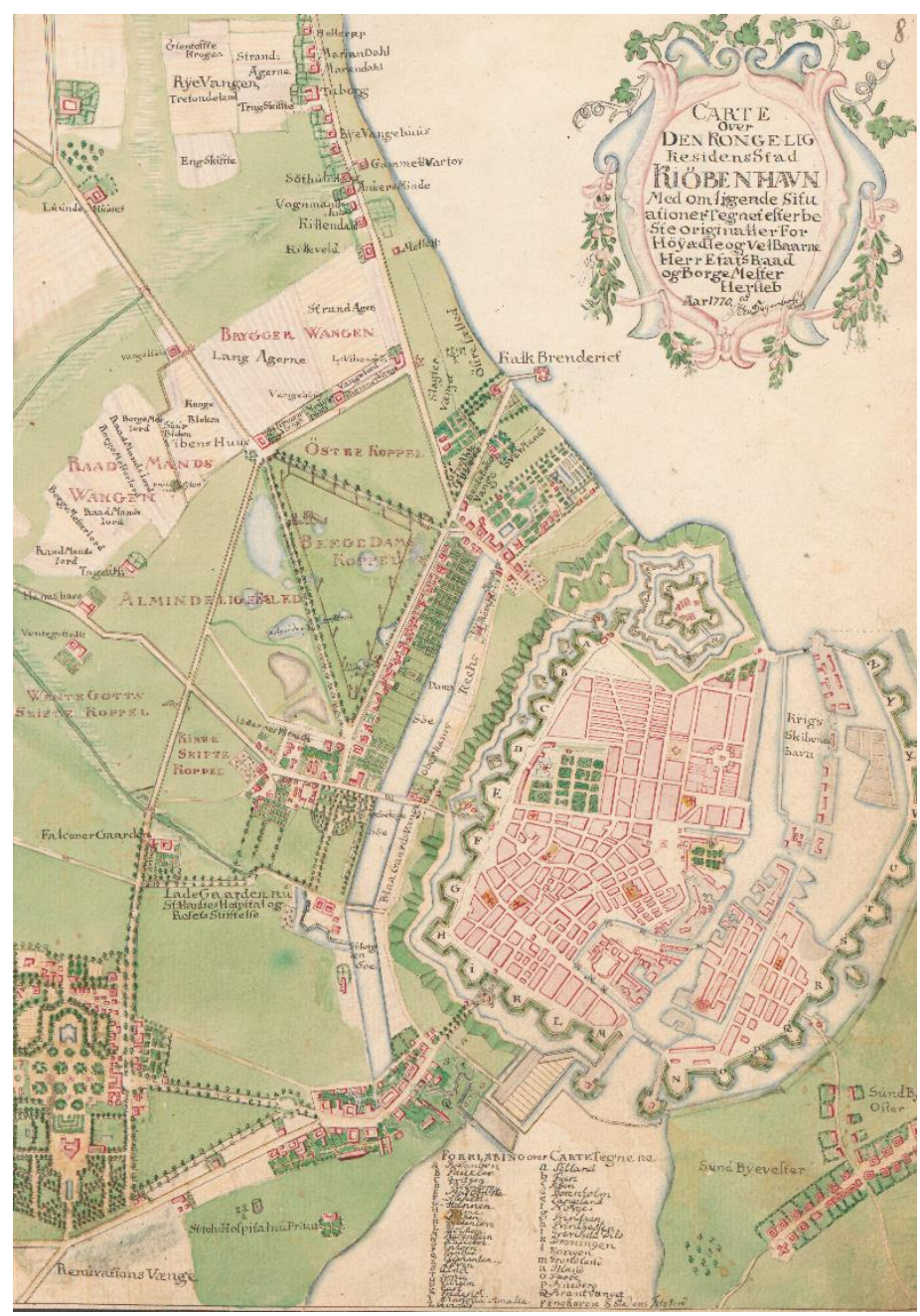

Det fastningsindesparrede Kфbenhavn, stadens uden for liggende grund på de senere brokvarterer samt nederst til venstre Frederiksberg Sogn med Frederiksberg by og slot. Kort 1770. (Københavns Stadsarkiv)

De dele af Københavns opland, der ikke inddroges til kongelige slotte og jagtområder, fabriksanlæg eller landsteder, blev drevet som landbrug af fæstebønder i landsbyerne på det helt overvejende krongods i hovedstadsoplandet. Da den hastigt voksende hovedstad ikke kunne brødføde sig selv og 
var afhængig af forsyning af fødevarer, brændsel m.m. udefra, blev krongodset fast leverandør til byen og dens institutioner. Efterhånden i en sådan grad, at det sugede oplandshandelen ud af de nærmeste købstæder Køge og Roskilde. Selv om der ude i sognene overalt fandtes en almindelig jordbrugsproduktion i form af kornavl og kreaturhold, specialiseredes produktionen og dermed leverancerne til hovedstaden efter de lokale naturgivne forhold og dyrkningsformer: Korn og mælk fra Vestegnen, tørv fra Nordvestegnen, træ og trækul fra Nordegnen, havets rigdom fra fiskerlejerne langs Øresund og grøntsager fra Amager.

I modsætning til andre dele af landet med krongodskoncentration, blev kun en mindre del af det store sammenhængende krongods i hovedstadsoplandet bortsolgt som hovedgårdsparter: B1.a. Edelgave Gjeddesdal i 1670’erne og Benzonsdal i 1730’erne. Ved landboreformerne i den sidste halvdel af 1700 overgik derfor størstedelen af fæstegårdene, ofte i lige linje, fra kronen til selveje eller arvefæste eller blev en art proprietærgårde. I Ny Amager, der efterhånden havde taget navn efter slottet Frederiksberg, havde de jordløse bønder været henvist til gårdenes havejord og ellers ulovlig tuskhandel, håndværk og gæstgiveri, som kronen så gennem fingrene med, samt de arbejdsopgaver, som slottet kastede af sig. I 1740’erne fik bønderne her den sydvestlige del af Hømarken i fæste og blev, efter at have afgivet jord til den nye Roskildevej, i 1775 også selvejere.

Som andre steder i landet blev det gamle dyrkningsfællesskab i Københavnsegnens landsbyer opløst ved landboreformerne: Bymarkerne udskiftedes, nogle gårde flyttede ud på markerne, og der oprettedes husmandssteder på de mere marginale jorder for at sikre arbejdskraftsforsyningen til gårdmænd og godser. På dette grundlag og som følge af selvejet blev egnens landbrug som andre steder i landet i den første halvdel af det 19. århundrede i stand til at deltage i dækning af den øgede udenlandske efterspørgsel på danske landbrugsvarer og kunne samtidig forsyne den stadig større hovedstadsbefolkning. Det blev fortrinsvis gårdmandsklassen og godserne, der vandt på udviklingen, og som genererede midler til mere effektive dyrkningsmetoder, opdyrkning af overdrev, tørlægning af vådområder og efterhånden efterspørgsel på færdigvarer. ${ }^{3}$

\section{Metropolkærnen opbygges - 1850-1914}

Som Danmarks eneste storby i europæisk skala havde København og det omgivende opland i midten af de 19. århundrede som det eneste regionale område særlige historiske forudsætninger for i de næste 150 år at blive landets eneste metropol. Med den voldsom befolknings- og bebyggelsesmæssige fortætning, der fulgte af det industrielle gennembrud, sprængte København sig i 1852 ud af enevældens og den førindustrielle tids fæstningsværker, og hovedstaden bredte sig i de følgende årtier ind over det umiddelbare opland. De københavnske broer skød op og udbyggedes, Frederiksberg forvandledes fra en landsby til en storby, og der begyndte at opstå bybebyggelser i de i København i 1901-1902 indlemmede distrikter og på de frederiksbergske vestlige yderdistrikter. Omkring udbruddet af første verdenskrig i 1914 havde København og Frederiksberg udviklet sig til en integreret hovedstad med et folketal på knap en halv million indbyggere, svarende til mere en fjerdedel af landets befolkning, og var samtidig blevet kerne i den hovedstadsmetropol, der omfattede en ydre periferi af villabyforstæder opstået længere ude i Hellerup, Charlottenlund, Klampenborg og Søborg (tabel 2).

I den urbaniseringsproces afvikledes efterhånden ældre fabriksanlæg og boligområder i Københavns indre og tidligere førindustrielle bydel, der i stadig grad udviklede sig til et cityområde med specialiseret og eksklusiv detailhandel, landets centraladministration, videregående uddannelsesinstitutioner, kulturinstitutioner, hovedsæderne for banker, kreditforeninger, rederier, industrivirksomheder og interesseorganisationer samt en stribe af liberale erhverv. Inden for det 
stadig mere integrerede bysamfund, som København og Frederiksberg som hovedstad kom til at udgøre, kom Københavns indre by dermed indtil videre til at udgøre bysamfundets kerne, center, mens de københavnske brokvarterer og det østlige Frederiksberg, der fik sit eget bycentrum ved byens nye banegård, foreløbig blev dets periferi.

Tabel 2. Befolkningsudvikling i hovedstadsmetropolen, Øvrige Sjælland og Danmark, 1800-1970

\begin{tabular}{|c|c|c|c|c|c|}
\hline \multicolumn{6}{|c|}{ Befolkningstilvækst i procent hovedstadsmetropolen, øvrige Sjælland og Danmark, 1800-1970 } \\
\hline I perioderne: & $1800-1850$ & $1850-1900$ & $1900-1950$ & $1950-1960$ & $1960-1970$ \\
\hline Hovedstadsmetropolen & 42 & 137 & 114 & 12 & 7 \\
\hline$\varnothing v$ rige Sjælland & 57 & 28 & 26 & 1 & 5 \\
\hline Danmark & 52 & 74 & 74 & 7 & 5 \\
\hline \multicolumn{6}{|c|}{ Hovedstadsmetropolens procentvise andel af Danmarks befolkning, 1800-1970 } \\
\hline 1800 & 1850 & 1900 & 1950 & 1960 & 1970 \\
\hline 21 & 18 & 25 & 32 & 34 & 35 \\
\hline
\end{tabular}

Kilde: Statisk Årbog for København, Frederiksberg m.m., 1981, s. 244. Öresundsregionen, 1969, s. 40-42.

Hovedparten af centrets tidligere fabrikker og en betydelig del af dets af befolkningen, nyetablerede industrivirksomheder og den meget omfattende indvandring til hovedstaden, blev således lokaliseret til periferien, hvor der var større friarealer og lavere grundpriser. De indre brokvartererne og det $\emptyset$ stlige Frederiksbergs bykvarterer, der op mod århundredskiftet kom til at lægge sig som et første koncentrisk bylag uden om Københavns indre bydel, blev dermed i stadig højere grad tyngdepunktet for hovedstadens landsdækkende og regionalt orienterede industriproduktion, og leverede som boligområder samtidig arbejdskraften til både disse erhverv og dem, der forblev og voksede frem i cityområdet. En arbejdskraft, der fordeltes på boligområder, som omfattede både tæt, planløst bebyggede og erhvervsmæssigt stærkt opblandede industri- og arbejderkvarterer på indre Nørre- og Vesterbro og Frederiksberg og villakvarter på andre dele af Frederiksberg og på det indre Østerbro.

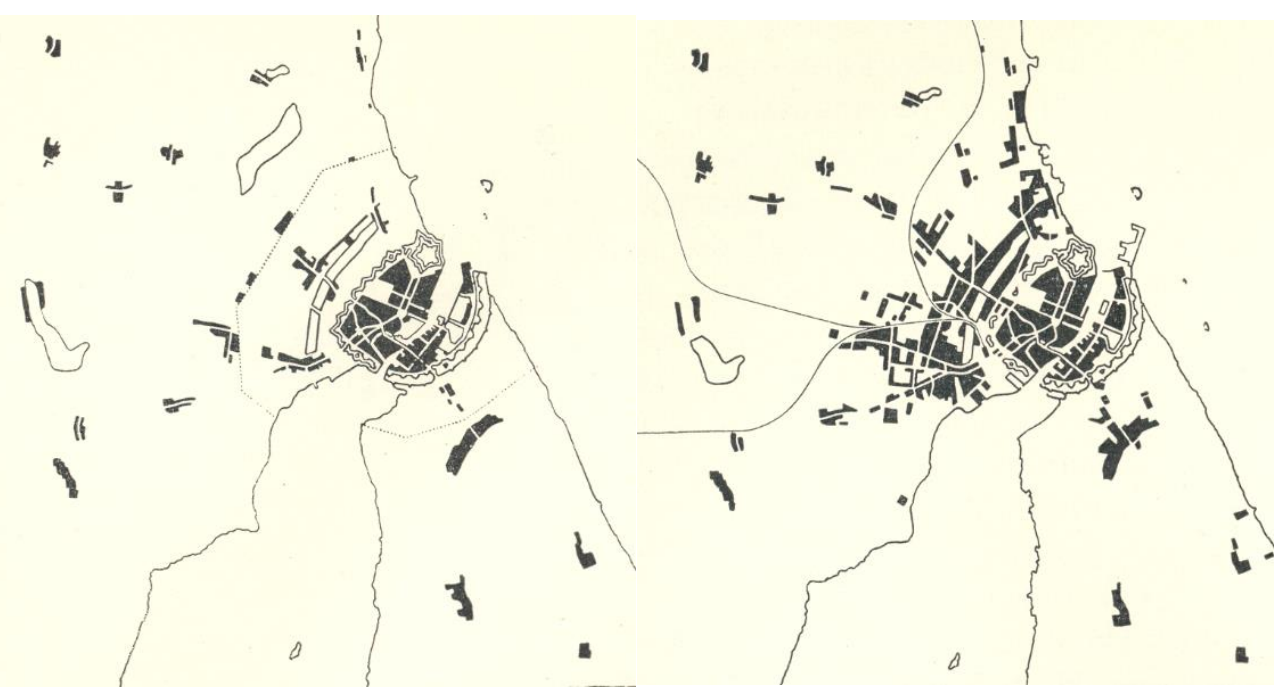

Hovedstadens bebyggelse. Til venstre: 1840. Til højre: 1900. (Holm og Johansen: Kфbenhavn 1840-1940, 1940

Med den forstærkede by- og industritilvækst fulgte på de ydre broer og på Frederiksbergs vestlige bykvarterer frem til Fasanvejslinjen i årtierne omring århundredeskiftet et andet og bredere koncentrisk bylag uden om det første med rene industrikvarterer i tilknytning til tidens nye havneanlæg og nye og planlagte jernbanelinjeføringer. Tæt ved de nye industrikvarterer, og som oftest i samme bydele, koncentreredes i samme bylag desuden kvarterer med boligkarrébebyggelser for arbejdere og lign. og nye villakvarterer for hovedstadens højeste indkomstlag. I et tredje koncentrisk bylag, der, i form af de i København i 1901-1902 indlemmende distrikter og de frederiksbergske yderdistrikter, på samme tid 
begyndte at lægge sig uden om det andet bylag, blev grunden samtidig lagt til meget store industriområder, ligesom der her opstod villakvarterer og mindre sammenhængende områder med andet etagebyggeri. Mens både det andet og tredje bylag som periferi blev integreret i den samlede hovedstad, blev de uden om liggende nordforstæder, på nær industrikvarteret ved Tuborg, rene boligområder. ${ }^{4}$

\section{Hovedstadsmetropolen vokser frem - mellemkrigstid og 40’erne}

Op gennem den første halvdel af det 20. århundrede udbyggedes hovedstaden, København og Frederiksberg, og nåede i 1950 et folketal på 880.000. Samtidig kom der for alvor så meget skred i forstadsdannelsen uden om, at befolkningen i midten af århundredet her nåede op på godt 300.000. Hovedstaden havde med sine forstæder dermed udviklet sig til en hovedstadsmetropol. En byregion, der med en befolkningstilvækst på 114 procent siden år 1900 havde opnået et folketal på mere end 1,2 mio. indbyggere, svarende til 32 procent af landets befolkning og med en geografisk udbredelse på $10-20 \mathrm{~km}$.

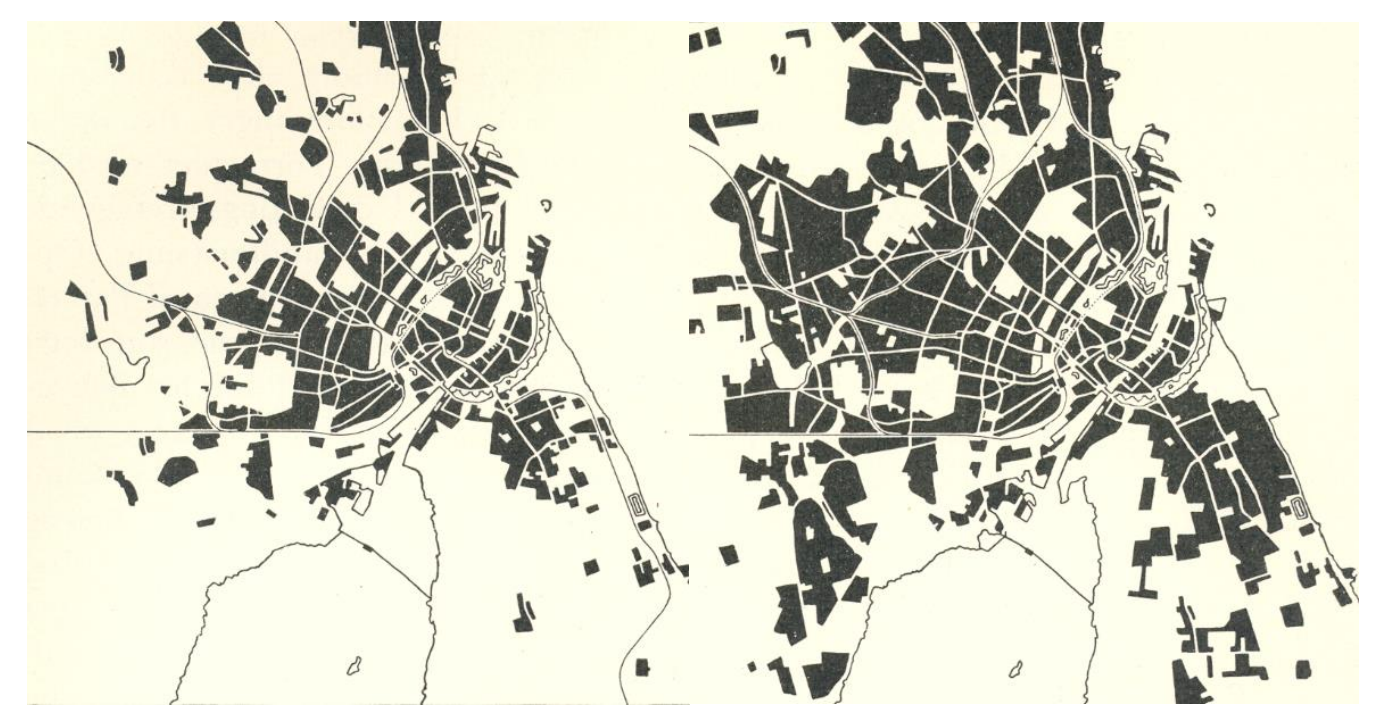

Hovedstadens bebyggelse. Til venstre: 1920. Til højre: 1940. (Holm og Johansen: Kфbenhavn 1840-1940, 1940)

I hovedstaden udbyggedes i perioden de distrikter, der var blevet indlemmet i København i 19011902, og Frederiksbergs vestlige yderdistrikter. Anlægget af og udbygningen af Sydhavnen og hovedstadens forholdsvis nyetablerede og planlagte jernbanelinjer bevirkede, at det yderligere fabriksbyggeri, som periodens fortsatte industritilvækst krævede, blev lokaliseret til de omfattende og mere isolerede industrikvarterer, der lå nær disse trafiklinjer, og således voksede frem i grænseområdet mellem det andet bylag, der var opstået frem til tiden omkring første verdenskrig, og det tredje lag, som de fremvoksende bydele i Københavns indlemmede distrikter og Frederiksbergs yderdistrikter kom til at udgøre. Ydre bydele, der på samme tid udbyggedes med boligbebyggelser og fik en mere socialt opblandet karakter end i de ældre bylag som følge af forskellige boligstørrelser i både kulissebyggeriet ved de her gennemgående gader og i de kvarterer med etagebyggeri, der udlagdes tæt ved de vidtstrakte villakvarterer.

Samtidig med hovedstadens udbygning opstod udenfor op gennem det 20. århundredes første halvdel endnu et koncentrisk bylag af forstæder, der i første omgang ikke i større omfang kom til at rumme industri eller andre byerhverv, og dermed fik karakter af boligforstæder med overvejende villakvarterer. Boligforstæder, der som hen mod slutningen af perioden tillige kom til at omfatte kvarterer med etagebyggeri i form af boligblokke i parklignende bebyggelser. Mens boligbebyggelsernes forskellighed med hensyn til boligstørrelse og bebyggelsesmåde blev rammesættende for de enkelte bydeles og kvarterers sociale karakter både i hovedstaden og i de enkelte forstæder, blev forstadsbylaget tidligt socialt opdelt i en større 
skala. Fra forstadsbæltet langs Øresund for samfundets absolutte overklasse kom hovedstadsmetropolens forstadsdannelser, i takt med hovedstadens bebyggelses- og befolkningsmæssige opfyldning, med faldende grundværdier og dermed også faldende indkomst og social status til at lægge sig som et halvcirkelslag i sydvestlig retning.

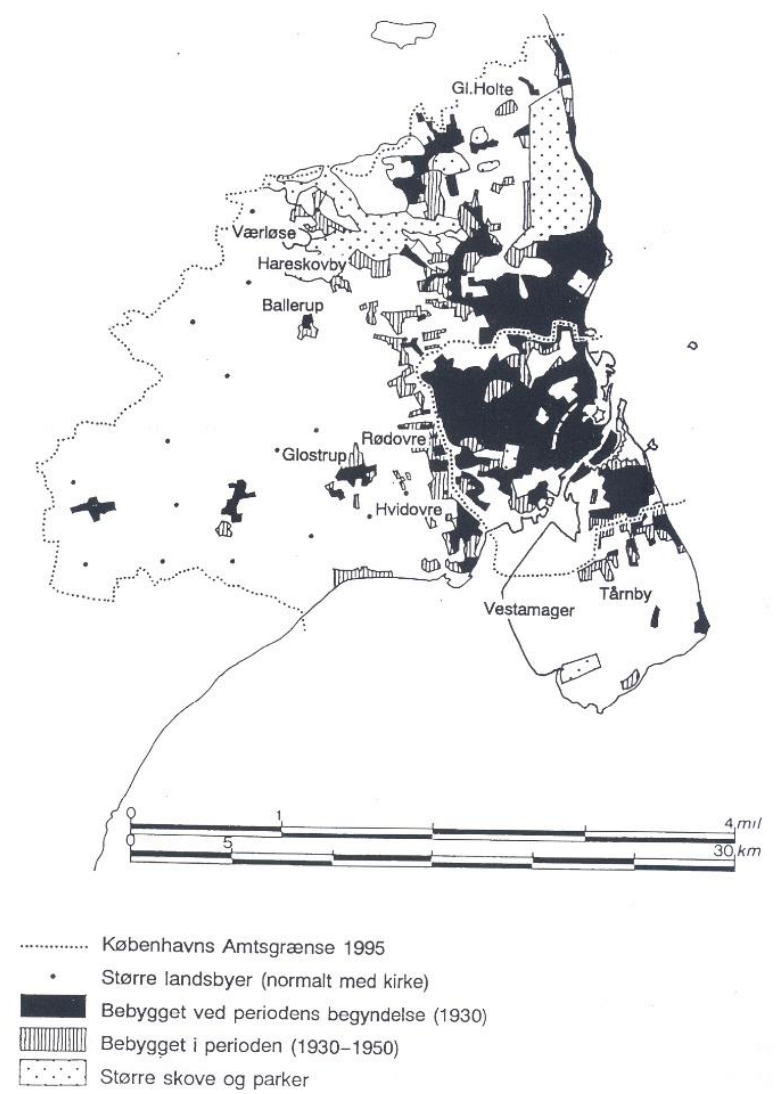

Bebyggelse i hovedstaden og Kфbenhavns Amtskommune 1930-1950 (Kulturhistorisk oversigt, Kфbenhavns Amtskommune, 1999)

Med etablering af omfattende nye fabrikskvarterer i hovedstadens yderdiskriter og begyndende udlægning af nogle af de fortsat ekspanderende store centrale statsinstitutioner fra city i

Københavns indre by til brokvartererne og det østlige Frederiksberg, kunne hovedstaden forstærke sin position som landets tyngdepunkt for industriproduktion og privat og statslig administrationsog servicevirksomhed. Hele hovedstaden blev dermed center eller kernen i hovedstadsmetropolen, mens forstæderne som boligbyer blev den periferi, der leverede arbejdskraften til kernens produktions- og servicevirksomheder. ${ }^{5}$

\section{Hovedstadsmetropolen i vækst - den første efterkrigstid}

Op igennem de første efterkrigsårtier udbyggedes hovedstadsmetropolen i et sådant omfang, at den i 1970 nåede et samlet folketal på over 1,7 mio., svarende til 35 procent af landet befolkning, og omfattede selve hovedstaden og Københavns, Frederiksborg og Roskilde amtskommuner. Væksten blev kendetegnet af meget omfattende forstadsdannelser. Først i form af en udbygning af de forstæder, der var opstået frem til midten af århundredet, hvorved der dannedes et $5-15 \mathrm{~km}$ bredt koncentrisk forstadsbælte uden om hovedstaden fra Øresundkysten i nordøst til Køge Bugt i sydvest. Selv om forstadsudbygning i den første tid således fandt sted inden for et fjerde bylag i hovedstadsmetropolen, brød forstadstilvækstens arealkrav til nyt industri-og boligbyggeri allerede i 50 'erne med det koncentriske urbaniseringsforløb. Herved fik de nye forstadsdannelser karakter af 
stadig mere landstrakte radiale bybånd, der, adskilt fra hinanden af stadigt bredere grønne og rekreative kiler, i længder af 30-40 km efterhånden kom til at flyde sammen købstæderne i den omliggende købstadsring og de uden for liggende satellit- og pendlerbyer i ældre stations- og landsbyer.

Som følge af betydelige ubebyggede arealer og dermed lavere grundværdier, blev først forstæderne i Gladsaxe og Tårnby kommuner og siden dem på Nordvest- og Vestegnen samt i Køge Bugtområdet i det 20. århundredes sidste halvdel kendetegnet af såvel arealkrævende nyetableret og tilflyttet eksportorienteret, landsdækkende og mere regionalt orienteret industri som store områder med mindre parcel- og rækkehuse og almennyttig boligbebyggelse fortrinsvis for arbejdere og lavere funktionærer. Herved forstærkedes den sociale opdeling, som hovedstadsmetropolens forstadsområde havde fået i midten af århundredet, idet særlig nordforstæderne fik karakter af boligbyer kendetegnet af vidtstrakte naturområder og overvejende privat byggeri af villaer på store grundarealer.
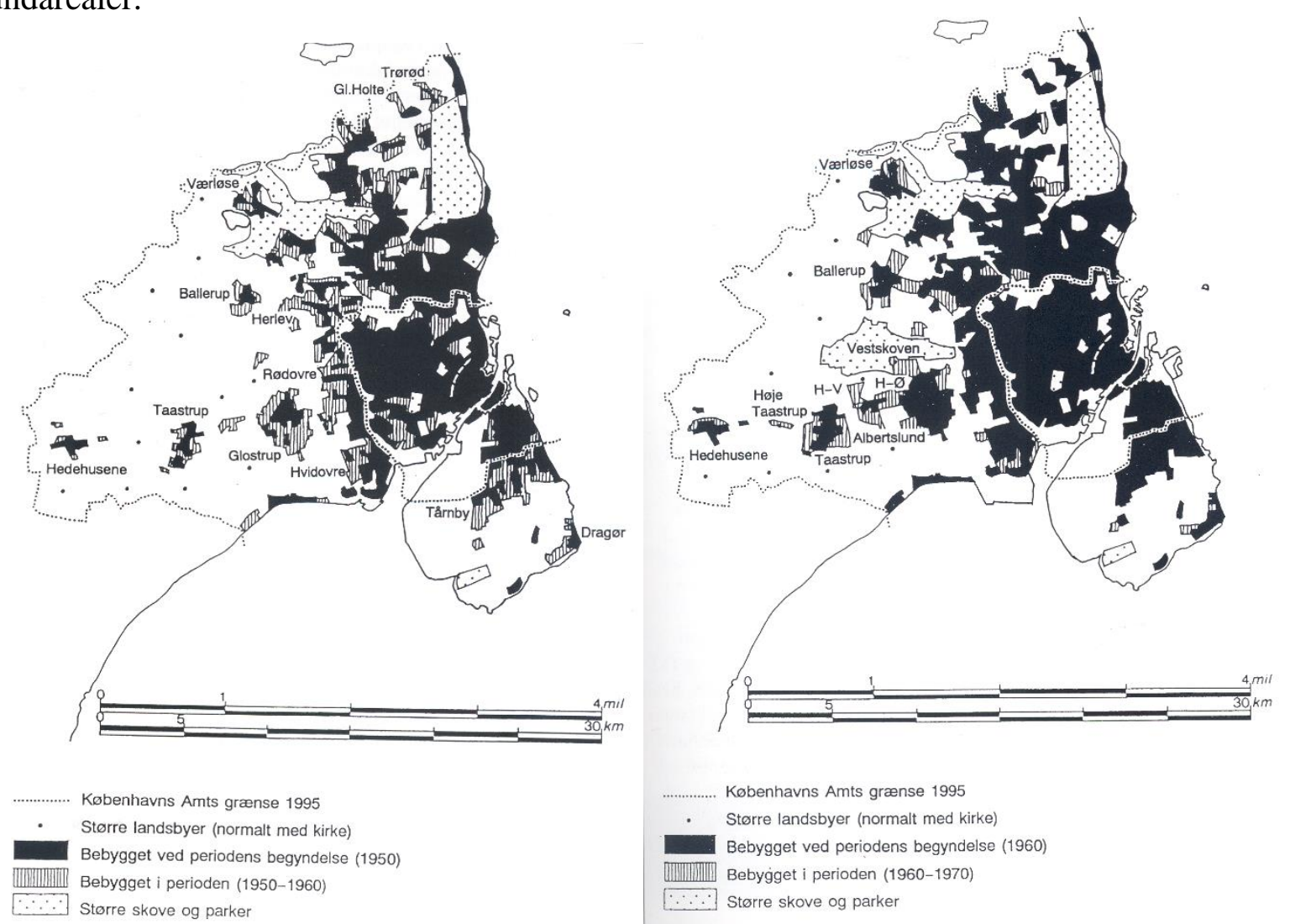

Bebyggelse i hovedstaden og Kфbenhavns Amtskommune. Til venstre: 1950-1960. Til højre: 1969-1970 (Kulturhistorisk oversigt, Kobenhavns Amtskommune, 1999)

Med den massive forstadsdannelse og byvæksten i den omliggende købstadsring og dennes satellitog pendlerbyer, fulgte omfattende befolknings- og erhvervsmæssige forskydninger, der førte til en signifikant forandring i interaktionen imellem bydannelserne i hovedstadsmetropolens periferi, mellem disse og hovedstadsmetropolens center, selve hovedstaden. Mens nogle forstæder overvejende forblev boligforstæder, og dermed i forhold til hovedstaden kom til at indgå i den centrum-periferirelation, som herskede før 1950, blev de nordvestlige og sydvestlige forstadsområder, ud over funktionen som boligbyer, hovedstadsmetropolens tyngdepunkt for produktions-, lager- og transportvirksomhed, hvortil der tillige pendledes fra boligforstæder og hovedstaden. 
I modsætning hertil blev hovedstaden i perioden kendetegnet af en stadig større afvandring og afindustrialisering. Mens folketallet i forstæderne og satellitbyerne i Københavns, Frederiksborg og Roskilde amtskommuner næsten fordobledes mellem 1950 og 1970, faldt det i samme periode med 12 procent i hovedstaden. Ud over et betydeligt fødselsoverskud og tilflytning fra provinsen, genereredes forstædernes befolkningstilvækst af en massiv udflytning fra hovedstaden, der allerede i midten af århundredet stort set var blevet udbygget og havde nået sit befolknings- og erhvervsmæssige mætningspunkt. Med byfortætningen var mulighederne for nyt industribyggeri og udvidelse af eksisterende fabriksanlæg i hovedstaden samtidig umuliggjort, mens forstæderne og de omliggende købstæder kunne tilbyde hovedstadsudflyttet eller nyetableret industri byggegrundene, der var billigere, og som havde en tilstrækkelig størrelse til den moderne industris mere pladskrævende produktionsbygninger og bedre tilkørselsforhold fra jernbane- og motorvejsnettet. I takt med afindustrialiseringen blev hovedstaden op gennem de første efterkrigsårtier i stadig højere grad erhvervsmæssigt kendetegnet af de styrende funktioner, der gennem privat og offentlig administrations- og servicevirksomhed udgik herfra, og blev rammesættende for produktionsvirksomheder og offentlig service, både regionalt og nationalt. ${ }^{6}$

\section{Hovedstadsmetropolen i stagnation og krise -den sidste efterkrigstid}

Havde hovedstadsmetropolen i den første efterkrigstid været kendetegnet af en massiv befolkningsog bymæssig tilvækst, reduceredes dens folketal op gennem 70’og 80'erne med 2 procent (tabel 3 ). Hovedstadsmetropolen fastholdt ganske vist et folketal på over 1,7 mio., men den sidste efterkrigstids befolkningsudvikling indikerede, at dens altdominerende rolle både i det dansk bysystem og som hovedgenerator for Øresundsregionens vækst og mulige integration blev svækket i disse årtier.

Tabel 3. Hovedstadsmetropolen og Danmarks befolkningstal og dets fordeling, 1970-1990. Index: $1970=100$

\begin{tabular}{|l|r|r|r|}
\hline & 1970 & 1980 & 1990 \\
\hline \multicolumn{3}{|c|}{ Hovedstadsmetropolen } \\
\hline Hovedstaden & $100(41,3)$ & $81(33,6)$ & $71(32,3)$ \\
\hline Københavns Amtskommune & $100(35,1)$ & $102(35,9)$ & $98(35,1)$ \\
\hline Frederiksborg Amtskommune & $100(14,8)$ & $127(18,9)$ & $132(19,9)$ \\
\hline Roskilde Amtskommune & $100(8,8)$ & $132(11,6)$ & $144(12,7)$ \\
\hline Hovedstadsmetropolen & $100[34,8]$ & $100[34,0]$ & $98[33,9]$ \\
\hline \multicolumn{4}{|c|}{ Danmark } \\
\hline Byer > 100.000 indbyggere & 100 & 95 & 98 \\
\hline Byer 10.000-99.999 indbyggere & 100 & 102 & 108 \\
\hline Byer 1.000-9.999 indbyggere & 100 & 148 & 187 \\
\hline Landdistrikter & 100 & 83 & 104 \\
\hline Hele landet & 100 & 103 & . \\
\hline
\end{tabular}

Kilde: Henning Bro: Metropoludfordringer, 2019.s. 120. Anm.: Alm. parentes: Procentandele af Hovedstadens og de indre forstæders samlede folketal og af hele hovedstadsmetropolens. Kantet parentes: Procentandel af hele landets befolkning.

Mens den bebyggelsesmæssige opfyldning af de indre forstæder i Københavns Amtskommune i perioden alene førte til samme fald i folketallet som i hovedstadsmetropolens som helhed, mistede hovedstaden således næsten 205.000 indbyggere. Et fald i dens befolkning på næsten 30 procent genereret af en i forhold til den første efterkrigstid voldsommere afvandring og det stigende fødselsunderskud, som fulgte af unge og yngres udflytning fra hovedstaden og den stadig større gruppe af ældre over 65, der blev tilbage. At hovedstadsmetropolens samlede folketal i 70'- og $80^{\prime}$ erne trods hovedstadens massive befolkningstilbagegang kun kom til udvise en svagt vigende tendens, var betinget af en samlet befolkningstilvækst på mere end en tredjedel i de ydre amtskommuner, hvor en væsentlig del af tidens nye bolig- og erhvervsbyggeri blev henlagt. 
Set i forhold til det $\varnothing$ vrige land blev befolkningstabet i hovedstaden mellem 1970 og 1990 større end i de danske landdistrikter, mens befolkningsudviklingen i selve hovedstadsmetropolen og i de indre forstæder i Københavns Amtskommune kom til at ligge på niveau med Danmarks største byer på over 100.000 indbyggere, men under Danmark som helhed. De ydre forstadsamtskommuners befolkningstilvækst blev derimod større end de 4 og 8 procent, der kendetegnede landets folketal og byer mellem 10.000 og 100.000, men nåede ikke småbyernes, med mellem 1.000 og 10.000 indbyggere, vækstrate på over 50 procent. I forhold til 1970 var hovedstadsmetropolens andel af Danmarks befolkning i 1990 dermed faldet fra 35 til 34 procent, mens dens befolkningsandel af landets bymæssige bebyggelser i samme periode var blevet reduceret fra 57 til 40 procent. Op gennem de sidste efterkrigsårtier skete der således på ny en demografisk udjævning mellem hovedstadsmetropolen og det $\varnothing$ vrige land og navnlig andre dets byer. En befolkningsmæssige udjævning mellem hovedstadsmetropolen og provinsen, der blev genereret af en svagere stigning i erhvervsbeskæftigelsen i hovedstadsmetropolen end i det $\varnothing$ vrige land (tabel 4). Mens landet som helhed i 70'- og 80'erne kunne notere en forøgelse af antallet af erhvervsbeskæftigede på 13 procent, blev stigningen i hovedstadsmetropolen alene på 7 procent, hvorved metropolens andel af landets erhvervsbeskæftigede faldt med 2 procentpoint. Den stigende erhvervsbeskæftigelse, som metropolen trods alt opnåede, blev skabt i de ydre amtskommuner, mens Københavns Amtskommune og hovedstaden i perioden kunne notere et fald på henholdsvis 2 og 15 procent.

Bag de erhvervsmæssige forskydninger mellem hovedstadsmetropolen og det Øvrige land og i selve metropolområdet, lå betydelige forandringer i selve industribeskæftigelsen. Som følge af industriens teknologiske udvikling, flytning af virksomheder uden for landets grænser,

konkurrence fra større enheder, industrilukninger og de alvorlige samfunds $\varnothing$ konomiske kriser, der, i den første del af 70'erne, i årene omkring 1980 og igen fra slutningen af 80'erne og ind i 90'erne, bidrog til denne udviklingstendens, reduceredes beskæftigelsen i dansk industri i årene 1970-1990 med 20 procent (tabel 5). Da de forudgåendes årtiers industriudvikling var mere vedholdende $\mathrm{i}$ provinsen og særligt i Jylland, blev det industrielle tilbageslag særligt udtalt i hovedstadsmetropolen, der med et samlet tab på 45 procent af industriarbejdspladserne, fra en andel på 38 procent af landets industribeskæftigede i 1970, 20 år efter var nået ned på en andel på 26 procent af samme.

Tabel 4. Den danske befolkningens erhvervsbeskæftigede, 1970-1990. Index: 1970=100

\begin{tabular}{|l|l|l|l|}
\hline & 1970 & 1980 & 1990 \\
\hline Landbrug m.m. & $100(1,2)$ & $72(1,2)$ & $51(0,9)$ \\
\hline Industri og håndværk & $100(28,5)$ & $64(17,0)$ & $55(14,7)$ \\
\hline Byggeri og transport & $100(15,8)$ & $98(14,7)$ & $97(14,3)$ \\
\hline Handel og omsætning & $100(18,2)$ & $111(19,1)$ & $106(17,9)$ \\
\hline Tjenesteydende erhverv & $100(36,3)$ & $144(48,0)$ & $158(52,2)$ \\
\hline Hovedstaden & 100 & 112 & 85 \\
\hline Københavns Amtskommune & 100 & 100 & 98 \\
\hline Hele hovedstadsmetropolen & $100[36,2]$ & $106[36,7]$ & $107[34,3]$ \\
\hline Hele landet & 100 & 105 & 113 \\
\hline
\end{tabular}

Kilde: Henning Bro: Metropoludfordringer, 2019, s. 122. Anm: Alm. parentes: Den procentvise erhvervsfordeling i hovedstadsområdet. Kantet parentes: Hovedstadsmetropolens procentvise andel af landets beskæftigede. 


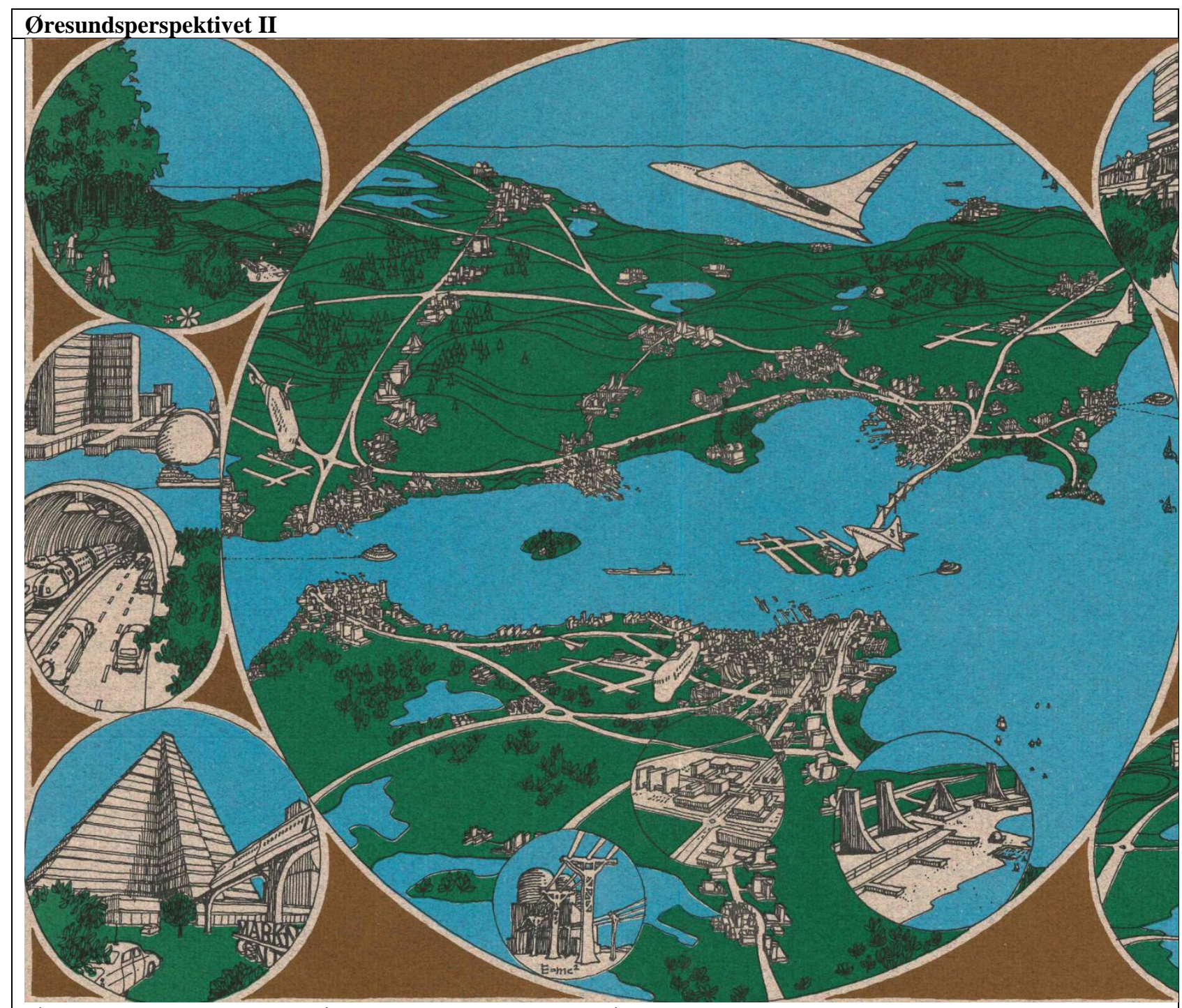

Øresundsrådets vision for en Øresundsmetropol i år 2000 (Øresundsregionen, 1969, s. 10)

Med en om end mindre ekspansiv, men til hovedstadsmetropolen svarende industrialisering og urbaniseringen i det vestskånske bybånd mellem Trelleborg og Helsingborg siden slutningen af det 1800-tallet og op gennem det følgende århundrede, trådte Skåne i stadig større grad ud af rækken af perifere svenske provinser og undergik en udvikling med betydelige parraller til den daske byregion på den anden side af Øresund. I lyset af den deraf følgende forøgede interaktion på tværs af Øresund og 60’ernes væksteufori, fremsættes forslag til faste forbindelser over sundet og visioner for en Øresundsmetropol. Mest vidtgående i den hvidbog, der i 1969 fremlagdes for Nordisk Råd af Øresundsrådet, der var blevet oprettet i 1961 med kommunale repræsentanter fra Øresundsregionen.

Øresundsrådets vision for en Øresundsmetropol i år 2000 lagde op til en, i modsætning til andre metropoler, stjerneformet flerkernet byregion med 4 mio. indbyggere forbundet og gennemskåret af motorveje og højhastighedsbaner. Ligesom enhver anden byregion ville Øresundsmetropolen være fuldstændig integreret både kommercielt og arbejdsmarkedsmæssigt såvel som kulturelt og socialt og være præget af et stærkt samspil mellem dets byer. På grund af den betydelige koncentration af forsknings- og uddannelsesinstitutioner og en højt kvalificeret arbejdsstyrke, ville Øresundsmetropolen være baseret på vidensintensiv og højt specialiseret industriproduktion inden for sektorer som biokemi, elektronik og det medicinske område samt private og offentlig serviceproduktion. Med dette potentiale ville den interskandinaviske byregion blive et kraftcenter, der ikke kunne dannes andetsteds i Norden, og ville stå stærkt i forhold til kontinentets byområder.

Den sidste efterkrigstids kriser og stagnation, der ramte byregionerne på begge sider af Øresund, gjorde foreløbig både en fast Øresundsforbindelse og visionen om en Øresundmetropol til et fatamorgana. 
Inden for hovedstadsmetropolens område blev tilbageslaget mest markant i selve hovedstaden, der i perioden mistede 64 procent af de industribeskæftigede. 50'ernes og 60'ernes udflytning af Københavns og Frederiksbergs industrivirksomheder og -arbejdspladser både til forstæderne og provinsen var således accelereret i de sidste efterkrigsårtier, og havde sammen med erhvervets $\emptyset$ vrige problemer bevirket, at hovedstadens andel af hovedstadsmetropolens samlede antal industribeskæftigede faldt fra 43 procent i 1970 til 28 procent i 1990. Også i hovedstadsamtskommunerne blev periodens fald i antal industribeskæftigede højere end på landsplan. Størst i forstæderne i Københavns Amt, hvor de samme udflytningstendenser som i hovedstaden var begyndt at gøre sig gældende, og havde resulteret i en nedgang $\mathrm{i}$ industribeskæftigelsen på 33 procent, og mindst i yderamterne med en nedgang på omkring en fjerdedel. Men langt fra så kraftigt som i København og på Frederiksberg, hvis udflyttede eller lukkede virksomheder bevirkede, at de tre hovedstadsamtskommuners andel af hovedstadsmetropolens industribeskæftigede forøgedes fra 35, 13 og 8 procent i 1970 til henholdsvis 43, 18 og 11 procent i 1990.

70- og 80'ernes fald i hovedstadsmetropolens samlede antal industribeskæftigede, blev dog modsvaret af en vækst $\mathrm{i}$ antal beskæftigede inden for de tjenesteydende erhverv på 58 procent. Herved forøgedes dette erhvervs andel af hovedstadsmetropolens beskæftigede i årene 1970-1990 fra 36 til 52 procent. Periodens yderlige udbygning af velfærdsstatens førte frem til midten af 80’erne til en fordobling af antal offentligt ansatte, hvorefter væksten var næsten stagnerende. Denne udbygning tilgodeså både forvaltning og institutioner i hovedstadsmetropolen på såvel statsligt som amts- og primærkommunalt plan, og hertil kom den yderligere tilvækst i antal arbejdspladser i industriens og det $\emptyset$ vrige private erhvervslivs administrative sektor, som fulgte med kapitalkoncentrationen.

Tabel. 5. Industribeskæftigede, Danmark, 1970-1990. Index: 1970=100

\begin{tabular}{|l|c|c|c|}
\hline & 1970 & 1980 & 1990 \\
\hline Hovedstaden & $100(43,3)$ & $58(39,5)$ & $36(28,2)$ \\
\hline Københavns Amt & $100(35,0)$ & $67(36,7)$ & $67(42,7)$ \\
\hline Frederiksborg Amt & $100(13,3)$ & $76(16,2)$ & $76(18,3)$ \\
\hline Roskilde Amt & $100(8,4)$ & $59(7,6)$ & $72((10,8)$ \\
\hline Hele hovedstadsområdet & $100[37,5]$ & $64[25,3]$ & $55[25,7]$ \\
\hline Hele landet & 100 & 91 & 80 \\
\hline
\end{tabular}

Kilde: Henning Bro: Metropoludfordringer, 2019, s. 123. Anm.: Alm. parentes: Procentandel af industribeskæftigelsen i hovedstadsmetropolen. Kantet parentes: Hovedstadsmetropolens procentvise andel af industribeskæftigelsen i hele Danmark

Med en tilvækst i antal beskæftigede på 81 procent og en forøgelse af andelen af samtlige beskæftigede fra 33 procent i 1970 til 61 procent i 1990, slog de tjenesteydende erhverv særlig kraftigt igennem i hovedstaden. Mens 163 pr. 1.000 indbyggere i 1970 her var beskæftigede i erhvervene, drejede det sig i 1990 om ikke mindre end 411 i 1990. Velfærdsstatens udbygning og de forøgede administrative funktioner i det private erhvervsliv gjorde sig selvsagt også gældende i hovedstaden, men forstærkedes her af dens stilling som hjemsted for både den statslige centraladministration, statens store undervisnings- forsknings- og kulturinstitutioner, erhvervslivets og interesseorganisationernes hovedsæder og erhvervsrettede servicevirksomheder: Banker, forsikring, rådgivning, reklame, edb m.m. ${ }^{7}$ 


\section{Hovedstadsmetropolen forandring - de sidste årtier}

For at give hovedstadsmetropolen, og særlig selv hovedstaden, en styrkeposition, der både kunne trække byregionen ud af den sidste efterkrigstids stagnation og stille den stærkere i forhold til den konkurrence mellem Europas regioner, der fulgte af den øgede europæiske integration og den nye $\emptyset$ konomiske verdensorden, som satte sig igennem fra starten af 90`erne, blev der i årtierne omkring årtusindeskiftet gennemført en række vidtgående vækststimulerende dispositioner. Afgørende rammebetingelser ikke blot for den ekspansive udvikling, der i de seneste to-tre årtier kom til kendetegne hovedstadsmetropolen, men også for den samlede Øresundsregions udvikling og integration.

\section{Regionalplanlægningens nyorientering}

Under indtryk af de samfundsøkonomiske strukturforandringer, der med globaliseringen allerede begyndte at tegne sig i slutningen af 80'erne, blev den sidste efterkrigstids danske regionalt udjævnende landsplanlægning opgivet til fordel for et nyt udviklingsperspektiv. Allerede Hovedstadsrådets sidste regionalplan fra 1989 lagde således, før der overhovedet var indgået en regeringsaftale om opførelse af en Øresundsbro, op til en forlængelse af Amgermotorvejen til en kommende fast forbindelse over sundet, en ny jernbane hertil fra København H, en undergrundsbane i forlængelse af Frederiksberg-banen til Amagerbro samt en fremtidig bybebyggelse i et smalt bælte i den $\emptyset$ stre del af Vestamager og ellers udlæggelse af den $\emptyset$ vrige del af området til rekreative formål. Samme vækstperspektiv for hovedstadsmetropolen indgik i Miljøministeriets landsplanredegørelse fra samme år, hvor der opereredes med regionale landsdelscentre, store infrastrukturelle anlæg, såsom faste forbindelser over Storebælt, Øresund og Femern Bælt, og storbyregioner. Af disse tillagdes hovedstadsmetropolen størst vækstskabende betydning, idet denne ansås for at have en tilstrækkelig volumen til at kunne stå sig i konkurrencen med andre europæiske storbyer, mens mindre og mellemstore byer blev anset for at have begrænsede vækstpotentialer og skulle baseres på mere arbejdsintensiv industri og turisme.

Trods det meget markante tilbageslag for varetagelsen af hovedstadsmetropolens regionale udfordringer, som nedlæggelsen af Hovedstadsrådet medførte op gennem 90’erne, var de nu regionalt planlæggende to hovedstadskommuner og tre hovedstadskommuner ministerielt blevet pålagt at følge linjen i rådets regionsplan fra 1989, og i Miljøministeriets landsplanredegørelse fra 1992 blev vækstperspektivet yderligere udvidet for metropolens vedkommende. Blandt redegørelsens seks hovedmål pegedes der specifikt på en række konkrete plandispositioner, der, i et nært samspil med det vestskånske bybånd, markant ville styrke hovedstadsmetropolens position som en byregion af centraleuropæisk størrelse. I Regionsplanrevision 1997, som ministeriet gennemførte for at fastholde Regionsplan 1989s regionale perspektiv, videreførtes 1992landsplanredegørelse målsætninger for hovedstadsmetropolen. Regionsplanrevisionen opstillede herudover vækstbaserede strategier for nye erhvervsområder og samstemte såvel den regionale planlægning som den kollektive trafikbetjening med de mere lokale plandispositioner, der fulgte af de trafik- og byggeprojekter, som offentlige selskabskonstruktioner var i gang med at gennemføre.

Med oprettelsen af Hovedstadens Udviklingsråd, HUR, i år 2000 og af det afløsende regionale organ, Region Hovedstaden, i forbindelse med den såkaldte Strukturreform i 2007, fik hovedstadsmetropolen på ny regionale myndigheder til varetagelse af byregionens overordnede udfordringer og til på lige fod med Skåne Län at indgå i samarbejdet om integrationen i Øresundsregionen. ${ }^{8}$ Både HURs Regionsplan 2005 og Region Hovedstadens efterfølgende regionale udviklingsplaner fulgte op på og videreudviklede de udviklings- og vækstperspektiver for hovedstadsmetropolen, der var nedlagt i de tidligere regionsplaner og 1992-landsplanredegørelsen i 
form af en yderligere planmæssig styrkelse af hovedstadsmetropolen i samspil med den øvrige Øresundsregion. ${ }^{9}$ En tilsvarende styrkelse indgik tillige i landsplanredegørelsen fra 2006, der udover den byregion, som hovedstadsmetropolen i forvejen udgjorde, lagde op til en østjysk byregion med Aarhus som kerne. I de følgende år blev denne centraliseringsstruktur forstærket yderligere i de landsplandirektiver, der fra 2007 afløste regionsplanerne, og i andre landsplansmæssige skitser. KL kunne f.eks. i 2016 opdele landet i såkaldte business-regioner, hvor de største udgjordes af Business-region Århus og Greater Copenhagen, der var helt dominerende. Sidstnævnte omfattede således hele Sjælland og øerne, og var endog interskandinavisk, idet hele Skåne blev set som en del af denne byregion. Med udgangspunkt i de to storbyregioner tegnede der sig i den danske lands- og regionsplanlægning efterhånden endnu mere vidtrækkende og grænseoverskridende regionsperspektiver. I form af to megapoler omfattende: Dels Greater Copenhagen, Slesvig-Holsten og Hamborg, med den kommende Femern Bælt-forbindelse som sammenknyttede trafikal faktor, og på sigt tillige Sydsverige og det sydligste Norge med storbyregionerne Stockholm, Oslo og Gøteborg. Dels en bymæssig Jyllandskorridor med forbindelse fra den østjyske byregion sydover til Hamborg.

\section{Trafikal opgradering}

Med lands- og regionsplanlægnings meget betydelige vækstperspektiver for hovedstadsmetropolens udvikling, lagdes der i årtierne omkring årtusindeskiftet op til omfattende trafikale anlæg, der ikke alene ville styrke hovedstadsmetropolens position, men også Øresundsregionens og dens integration. I periodens forlængedes således Frederikssundsmotorvejen fra Ring 4 til Veks $\varnothing$, ligesom der gennemførtes udbygninger af eksisterende motorveje på de mest trafikbelastede strækninger. I form for Køge Bugt-motorvejens udvidelse fra seks til otte spor og udvidelser fra fire til seks spor på den indre del af Helsingørmotorvejen og på Motorring 3 og 4. Periodens opgradering af hovedstadsmetropolens trafikale infrastruktur blev dog mest markant på det kollektive trafikområde, der fik et signifikant løft.

Som konsekvens af beslutningen om opførslen af Øresundsbroen og den forventede større integration i Øresundsregionen stiftedes i 1992 tre baneselskaber: Ørestadsselskabet I/S, med staten og Københavns Kommune som ejere, samt Frederiksberg-baneselskabet og Østamagerbaneselskabet med Ørestadsselskabet og henholdsvis Frederiksberg Kommune og Københavns Amtskommune som medejere. Delvist finansieret af salget af Ørestadens byggegrunde, se nedenfor, etablerede de tre selskaber gennem den sidste halvdel af 90'erne og frem til 2003 en metro, der i de centrale dele af hovedstaden fik et forløb som undergrundsbane og ellers som højbane, fra den yderste del af Ørestaden og Indre Amagerbro, via Københavns indre bydel og Frederiksberg, til Vanløse Station. Med forlængelsen af metrogrenen fra Amagerbro til lufthavnen i 2007 stod den første etape af Metroen færdig.

I de følgende år etablerede Metroselskabet, som 2007 afløste de tre metroselskaber og fik staten og hovedstadskommunerne som ejere, den ringbanedel af Metroen, der åbnede i 2019, og som fik udgangspunkt fra Københavns Hovedbanegård og et forløb herfra gennem Københavns den indre bydel, Østerbro, Nørrebro, Frederiksberg, Vesterbro og derfra til hovedbanegården. Ringmetroen fik krydsningsstationer med den radialt gående metrolinje på Frederiksberg og Kgs. Nytorv og afgrenerlinjer til Nord- og Sydhavnen. Metroen fik desuden direkte forbindelse til fjerntogstrækningerne og regional- og Øresundstog ved krydsning af disses strækninger på Østerport, Nørreport, Københavns Hovedbanegård og Ørestad Station. 
Med åbningen af Øresundsbroen kunne hovedstadens hidtidige linjeføring for transitbanegods mellem Sverige og kontinentet, Danlink, afvikles, hvorved godsringbanen gennem de ydre dele af København og Frederiksberg mistede sin betydning som så. Fra Metroens krydsning af S-banerne til såvel Frederikssund som Hellerup og Valby, hvor den nye Flintholm Station placeredes, kunne godsringbanens sydlige del derfor omdannes til S-bane, hvorved hovedstaden fra 2005 fik en tværgående S-banelinje, der mellem Hellerup og Ny Ellebjerg krydsede samtlige af de radialt løbende S-baner.

Med staten som den drivende kraft fik hovedstaden og Amager med Metroen og den forlængede Sringbane et meget afgørende kollektivt trafikalt løft af afgørende betydning for dens befolknings- og erhvervsudvikling og pendlerstrømmene i hovedstaden og mellem denne og dens forstadsbånd, hovedstadsmetropolens ydre dele og Skåne. Med beslutningen i 2012 om etablering af en letbane fra Lyngby til Ish øj, der skulle anlægges og drives af staten, Region Hovedstaden og de omliggende kommuner, blev der endelig taget skridt til, at de indre forstadsområder i den tidligere Københavns Amtskommune kunne få den tiltrængte tværgående baneforbindelse.

Efter nedlæggelsen af Hovedstadsrådet i 1990 fortsatte dets regionale Hovedstadsområdets Trafikselskab, HT, som et selvstændigt selskab under ledelse af en bestyrelse bestående af repræsentanter for de nye ejer- og driftskommuner; de to hovedstadskommuner og de tre hovedstadsamtskommuner. På trods af regions- og landsplanlægningen høje prioritering af selve hovedstadens vækst blev HTs virksomhed i 90'erne imidlertid kendetegnet af sparerunder, tidens privatiseringer og udliciteringer af offentlig virksomhed og en udbygning af busnettet $i$ hovedstadsmetropolens forstæder. I form af såkaldte S-busser, med høj frekvens og korte rejsetider, på tværs af de radiale S-banelinjerne og særlige pendlerbusser fra S-banestationerne og ud til områder med en betydelig koncentration af arbejdspladser og uddannelsesinstitutioner.

Med oprettelsen af HUR overgik HT i år 2000 hertil for endelig fra 2007, at indgå i Region Hovedstaden, der sammen med Region Sjælland samlede HT, Storstrøms Trafikselskab og Vestsjælland Trafikselskab i det nye fælles regionale selskab Movia. Med HT's overførsel til HUR opnåedes på ny den sammenhæng mellem regionsplanlægning og den kollektive trafiks drift og planlægning, der havde manglet op gennem 90’erne. En sammenhæng der blev fastholdt af Movia, som tillige gennemførte en samlet styring og planlægning af bus- og privatbanedriften på hele Sjælland og omliggende øer. På samme tid etablerede HT og senere Movia i selve hovedstaden et stadig mere omfattende A-busnet med meget hyppig drift og efterhånden også med linjer ud til de inderste forstæder. Samlet kom HT og Movia i årtierne op til og særlig efter årtusindeskiftet til at yde et betydeligt bidrag til udbygningen af den kollektive trafik i hovedstadsmetropolen af stor betydning ikke blot for dens sammenhængskraft og dermed dens funktionalitet som en byregion, men også for pendling i hele Øresundsregionen.

\section{Byomdannelser}

Nok så afgørende rammebetingelser for hovedstadsmetropolens og selve hovedstadens vækst, og dermed også for hele Øresundsregionens udvikling og integration, blev de meget betydelige udlæg af friarealer til bybebyggelse, der gennemførtes i årtierne omkring årtusindeskiftet og de samtidige og meget omfattede byomdannelser af de ældre industri-, erhvervs- og trafikområder, der var kommet til at stå tilbage efter afviklingen af hovedstadens industri. Herved tilvejebragtes både en meget betydelig og tidssvarende boligmasse og nye store bygningskomplekser for offentlige institutioner, interesseorganisationer, private virksomheder, forretningscentre m.m. Med disse komplekser rykkede de city-, regions- og landsfunktioner, som før var koncentreret til Københavns indre by og Vestervold-kvarter, videre ud til de gamle 
københavnske industri- og havnekvarterer, Amager og Frederiksberg. Sammen med de byfornyelser af ældre bydele, der gennemførte på samme tid, blev hovedstaden ét samlet servicebysamfund med moderne boligbebyggelser og nye serviceproducerende erhverv i hovedparten af dens område.

For at etablere en ny bydel i tilknytning til de store trafikale tilslutningsanlæg til Øresundsbroen stiftedes i 1992 I/S Ørestadsselskabet; for 55 procents vedkommende ejet af Københavns Kommune og for de 45 procents af staten. Selskabet overtog den østlige del af det siden 1962 af staten og Københavns Kommune fællesejede Vestamager, der trods den meget centrale beliggenhed ikke var blevet udnyttet, som følge af den politisk uklare stilling for så vidt faste forbindelser over Øresund og lufthavnens fremtidige udbygning eller flytning. Ørestadsselskabet, der udrustedes med et sagkyndigt råd, Ørestadsrådet, skulle sammen med Københavns Kommune dels på grundlag af en helhedsplan planlægge og udvikle det overdragene område til en ny bydel med navnet Ørestad, dels anlægge bydelens overordnede veje og en metro gennem denne med videre forbindelse til den $\emptyset$ vrige del af hovedstaden. Indtægterne ved salget af byggegrundene i Ørestaden skulle anvendes til disse meget omkostningstunge anlægsprojekter.

Ørestaden var i dens bagvedliggende lovgivning tænkt som en pendant til Københavns city i den indre bydel tilpasset det $\emptyset$ vrige Vestamagers naturværdier. Den nordlige af Ørestad skulle i overvejende grad udlægges til videregående uddannelses- og forskningsinstitutioner, herunder bl.a. et udvidet campus for Københavns Universitet og et kommende IT-universitet, kulturelle anlæg, som bl.a. DR-byen, og boligområder. Mens boligbebyggelser i højere grad, udover det eksisterende og udvidede Bella Center, skulle dominere Ørestadens midterste og smalle del, skulle dens sydlige del, med centrum i Ørestadens fællesstation for Metroen og Øresundsbanen, i overvejende grad omfatte en citypræget bebyggelse i form af et storcenter, der senere blev til Fields, hoteller og kontorhøjhuse, som siden kom til at huse mange af de internationale virksomheder og skandinaviske og nordeuropæiske hovedsæder, der omkring årtusindeskiftet flyttede til Øresundsregionen. Herudover kom denne del af Ørestaden til at omfatte Metroens værkstedsområde, et gymnasium, kulturelle anlæg, som Ørestad Skøjtehal og Royal Arene, en naturskole, andre boligområder samt bolig- og erhvervskomplekset 8-tallet.

Da Københavns havne, der havde været drevet af en selvejende offentlig organisation, op gennem efterkrigstiden fik en stadig mindre omsætning, som følge af øget godstransport pr. lastbil, tog og flyv, mistede stadig større havneområder sin oprindelige betydning. For at byomdanne disse, ofte meget centralt beliggende, havneområder, oprettedes ved lov i 1992 den offentlige institution Københavns Havn, der udrustedes med en bestyrelse sammensat af seks medlemmer udpeget af staten og henholdsvis tre, et og to medlemmer udpeget af Københavns Kommune, Det Danske Handelskammer og havnenes medarbejdere. Københavns Havn skulle herefter dels drive havnevirksomheden i København, dels planlægge og gennemføre byomdannelsen af de havneområder, som ikke længere skulle anvendes til havneformål, dels sælge disse arealer. Institutionens bestyrelse skulle udforme den overordnede strategi for byomdannelsen, der siden skulle fastlægges i en dispositionsplan og løbende virkeliggøres gennem Københavns kommuneplanlægning.

For at muliggøre overførelsen af den københavnske havnevirksomhed til Copenhagen Malmö Port, og for samtidig at intensivere byudomdannelsen af dele af Københavns tidligere havneområder, omdannedes institutionen København Havn i år 2000 til det statslige Københavns Havn A/S, der dog nedlagdes i 2007 i forbindelse med nedlæggelsen Ørestadsselskabet og Frederiksbergbaneselskabet, hvis drift af Metroen samtidig overgik til Metroselskabet. Til 
planlægning og gennemførelse af byomdannelsen af de resterende dele af Nord- og Sydhavnen, Lynetten og Ørestaden oprettedes i stedet Arealudviklingsselskabet I/S, der året efter skiftede navn til I/S By og Havn med Københavns Kommune som ejer af 95 procent af virksomheden og staten som ejer af de resterende 5 procent. Som de hidtidige arealudviklingsselskaber, skulle I/S By og Havn forsat sælge de byomdannede områder med henblik på finansiering af den videre udbygning af Metroen.

Gennem den offentlige institution Københavns Havn, det efterfølgende statslige selskab af samme navn og siden I/S By og Havn byomdannedes, lige på nær en del af Nordhavnen, hovedparten af hovedstadens havneområder i årtierne omkring årtusindeskiftet til nye bydele med såvel boligområder, hoteller og kongrescentre som omfattede erhvervsområder med institutions-, forretnings- og kontorbyggeri for offentlige myndigheder og private virksomheder. Det gjaldt den sydlige del af Norhavnen, Kalvebod og Islands Brygges havne og Sydhavnen, som forsat $\mathrm{i}$ begrænset omfang kom til at huse ældre erhverv som f.eks. H.C. Ørstedsværket og mindre industri. Ud over disse gigantiske byomdannelser gennemførtes i samme periode helt tilsvarende omdannelser i dels en række af Københavns tidligere industrikvarterer ved Strandlodsvej og Amager Strandvej og i Valby og Lygtekvareret, dels ældre erhvervs- og industriområder på Frederiksberg.

På Frederiksberg byomdannedes NKTs tidligere fabriksområde til det nye kvarter Dalgas Have med boligbyggeri og fakultetsbygninger for CBS. Det gamle banegårdsområde med dets mægtig sporterræn i Frederiksbergs centrum omdannedes til Frederiksberg Centret, bygningskomplekser for et gymnasium og CBS og nye pladsdannelser, mens forsyningsværkernes tidligere arealer ved Finsensvej blev til den nye bydel Flintholm med både bolig-, institutions- og kontorbyggeri. Til gengæld bevaredes de gamle produktionsbygninger efter Den kongelige Porcelænsfabrik i Smallegade og støvsuger- og motorcykelfabrikken Fikser \& Nielsen på Peter Bangsvej på en sådan måde, at disse ombyggedes til bolig- og serviceerhvervsformål og suppleredes med nybyggeri med samme funktion.

Også ude i de forstæder, hvor ældre industrivirksomheder var forsvundet, gennemførtes tilsvarende byomdannesler; bl.a. i det centrale Lyngby, Gladsaxes industrikvarter øst for Hillerød-motorvejen og en række industriområder på Vestegnen. For at udvide de nærkreative områder, som havde betydning for befolkningen i den indre del af hovedstadsmetropolen, udbyggedes Hedeland på Vestegnen betragteligt, og da der var opnået gode erfaringer med Køge Bugt Strandpark, der anlagdes i slutningen af 70’erne, åbnedes i 2005 Amager Strandpark tæt ved de centrale dele af hovedstaden. Den 57 ha store strandpark kom til at omfatte en $2 \mathrm{~km}$ lang kunstig $\varnothing$ med sandstrande, en $400 \mathrm{~m}$ bred lagune ind til den oprindelige kystlinje, en 4,6 km lang badekyst samt toilet- og brusefaciliteter, kiosker, caféer, restauration og aktivitetsforretninger. Hertil kom den rekreative omdannelse af hovedparten af det vidstrakte Vestamager.

\section{De store forandringer}

Mens hovedstadsmetropolen i efterkrigstiden havde været kendetegnet af først en massiv afvandring fra og afindustrialisering $\mathrm{i}$ hovedstaden og en meget betydelig industriel og befolkningsmæssig tilvækst $\mathrm{i}$ forstæderne, de omliggende købstæder og satellitbyer og siden af stagnation og krise, bevirkede et samspil mellem internationale $\varnothing$ konomiske faktorer, Øresundsregions store trafikanlæg og integration, hovedstadsmetropolens, og særlig hovedstadens, trafikale opgradering og massive byomdannesler, at metropolen i årtierne omkring årtusindeskiftet på ny kom ind i en mere stabil vækstperiode, men også at der skete signifikante forskydninger i interaktionen mellem dens forskellige dele. 
For den stærkt eksportorienterede og importfølsomme danske industriproduktion fik periodens globale $\emptyset$ konomiske forandringer og den samtidige teknologiske udvikling betydelige konsekvenser. Den informationsteknologiske eksplosion førte således til effektiviseringer og koncentrationstendenser, samtidig med at en del af dansk industri bukkede under for den globale konkurrence, opkøbtes af udenlandske koncerner eller blev flyttet til lavtlønsområderne i den tredje verden eller Østeuropa. I 90'erne og i det nye årtusindes årtier fortsatte således faldet $\mathrm{i}$ antallet af virksomheder og beskæftigede i dansk industri, der nåede ned på godt 15 procent af landets samlede arbejdsstyrke. Til gengæld tilpassedes den tilbageværende og endnu betydelige industri på forskellig måde til de forandrede vilkår, samtidig med at de tjenesteydende erhverv tegnede sig for en stadig større vækst. Delvis i form af en vis vækst i den offentlige sektor, men navnlig som følge af en betydelig stigning i beskæftigelsen og i antallet af virksomheder inden for erhvervsorienteret servicevirksomhed. Med den informationsteknologiske revolution inden for både vareog serviceproduktion, produktionens specialisering og en stadig mere kompleks og internationaliseret $\emptyset$ konomi, blev IT, knowhow og forskning nye vigtige produktionsfaktorer. Det åbnede for store investeringer i erhvervsrettet serviceproduktion så som IT-udvikling og -drift, kommunikationstjenester, organisationsudvikling, medie- og reklametjenester, forskning, finans- og markedsorienteret virksomhed, privat service og konsulent- og rådgivningstjenester.

Tabel 6. Industribeskæftigede, Hovedstadsmetropolen, 1990-2000. Index: 1990=100

\begin{tabular}{|l|c|c|}
\hline & 1990 & 2000 \\
\hline Hovedstaden & $100(28,2)$ & $75(24,6)$ \\
\hline Københavns Amt & $100(42,7)$ & $87(43,3)$ \\
\hline Frederiksborg Amt & $100(18,3)$ & $92(19,7)$ \\
\hline Roskilde Amt & $100(10,8)$ & $98(12,4)$ \\
\hline Hele hovedstadsmetropolen & $100[25,7]$ & $86[24,4]$ \\
\hline Hele landet & 100 & 92 \\
\hline
\end{tabular}

Kilde: Statistisk årbog for København m.v., Københavns statistiske Årbog og Statistisk Årbog, 1993 og 2001. Anm.; Parentes: Procentandel af industribeskæftigelsen i hovedstadsområdet. Kantet parentes: Hovedstadsområdets procentvise andel af industribeskæftigelsen i hele Danmark.

De meget betydelige $\varnothing$ konomiske strukturforandringer, der således kom til at kendetegne det danske samfund i årtierne omkring årtusindeskiftet, førte til markante forskydninger mellem landets enkelte dele. I hovedstadsmetropolen fortsatte faldet $\mathrm{i}$ industribeskæftigelsen på ny kraftigere end i det øvrige Danmark, og nåede efter årtusindeskiftet under 8 procent af byregionens samlede arbejdsstyrke (tabel 6-7 og 9-11). Af hovedstadsmetropolens tilbageværende produktionserhverv klarede særlig den specialiserede industri sig. Den var baseret på nye brancher, højteknologi og en veluddannet arbejdskraft, og selv i kriseperioden efter 2008 kunne kemisk-, medicinal-, møbel-, og transportmiddelindustri udvise positive vækstrater i beskæftigelsen, mens tilbageslaget i samme periode blev mindre inden for metal- og levnedsmiddelindustri og produktion af eludstyr (tabel 8). Men det blev væksten i de tjenesteydende erhverv, handel og omsætning, der ikke blot modvirkede tabet af industriarbejdspladser, men også øgede beskæftigelsen mere i hovedstadsmetropolen end i resten af landet, hvorved byregionen på ny kunne tegne sig for en stigende andel af den samlede danske arbejdsstyrke.

Hovedstadsmetropolens koncentration af forskning og knowhow var afgørende for, at væksten inden for den private erhvervsrettede serviceproduktion blev særlig stærk her, hvilket bevirkede, at ikke mindre end halvdelen af landets arbejdspladser i denne branche kunne lokaliseres til byregionen. Herudover havde størsteparten af hovedsæderne for landets erhvervsvirksomheder og interesseorganisationer fortsat hjemsted i hovedstadsmetropolen, der ud over store amts- og primærkommunalsektorer husede overordnede offentlige institutioner og hovedparten af statens ansatte. Endelig blev hovedstadsmetropolen hjemsted for internationale produktionsvirksomheders skandinaviske eller nordeuropæiske hovedkontorer. Bl.a. for: Nokia, Ferring International Center, fødevarevirksomheden Nestlé, medicinalvirksomheden Nycomed, 
Gillette, Sony, biotekviksomheden Biogen, Mercedes Benz, fødevarefirmaet Masterfood, it-virksomheden Dell, Coca-Cola, NNS Financial, it-giganten Oracle, UCB Pharma og medicinalfirma Astelleas.

Hovedkontorer der enten nyoprettedes i Skandinavien eller flyttedes til hovedstadsmetropolen fra Nordtyskland, Stockholm og Oslo.

Tabel 7. Industribeskæftigede, hovedstadsmetropolen, 2008-2016. Index: 2008=100

\begin{tabular}{|l|c|c|}
\hline & 2008 & 2016 \\
\hline Hovedstaden & $100(22,8)$ & $97(21,9)$ \\
\hline Indre forstæder & $100(23,7)$ & $89(22,5)$ \\
\hline Nordsjælland & $100(26,8)$ & $100(28,8)$ \\
\hline Østsjælland & $100(26,7)$ & $88(26,8)$ \\
\hline Hovedstadsmetropolen & $100(100)$ & $94(100)$ \\
\hline
\end{tabular}

Kilde:

http://www.statistikbanken.dk/statbank5a/SelectVarVal/Define.asp?MainTable=AKU200\&PLanguage=0\&PXSId=0\& wsid=cftreeParentes: Anm.: Parentes: Procentandel af industribeskæftigelsen i hovedstadsmetropolen.

Med dette erhvervspotentiale og som følge af en nettotilvandring fra udlandet vendtes hovedstadsmetropolens befolkningsudvikling på ny efter den sidste efterkrigstids stagnation (tabel $12 \mathrm{og}$ fig. 1). Mens Danmark i 90’erne og i det nye årtusindes første årti fik en tilvækst i folketallet på otte procent, kunne hele hovedstadsmetropolen i samme periode notere en befolkningsforøgelse på elleve procent. Herved nåede metropolens samlede folketal, der før 1990 havde svinget omkring 1,7 mio. indbyggere, over 1,9 millioner, hvorved byregionen igen kunne tegne sig for en stigende andel af landets samlede befolkning.

Tabel 8. Industribeskæftigede fordelt på brancheområder, hovedstadsmetropolen, 2008-2016. Index: $2008=100$

\begin{tabular}{|l|c|c|}
\hline & 2008 & 2016 \\
\hline Levnedsmiddel & $100(16,3)$ & $83(14,4)$ \\
\hline Tekstil & $100(2,1)$ & $68(1,5)$ \\
\hline Træ- og papir & $100(8,5)$ & $58(5,2)$ \\
\hline Kemisk & $100(10,6)$ & $112(12,6)$ \\
\hline Medicinal & $100(22,5)$ & $145(34,8)$ \\
\hline Beton, glas, plast & $100(2,6)$ & $52(7,0)$ \\
\hline Metal & $100(11,5)$ & $70(8,5)$ \\
\hline Eludstyr & $100(3,8)$ & $93(3,7)$ \\
\hline Transportmiddel & $100(0,9)$ & $142(1,3)$ \\
\hline Møbel & $100(11,2)$ & $103(11,0)$ \\
\hline Hovedstadsmetropolen & $100(100)$ & $94(100)$ \\
\hline Kin: & & \\
\hline
\end{tabular}

Kilde:

http://www.statistikbanken.dk/statbank5a/SelectVarVal/Define.asp?MainTable=AKU200\&PLanguage=0\&PXSId=0\& wsid=cftree. Anm.: Parentes: Procentandel af den samlede antal industribeskæftigelsen i hovedstadsmetropolen.

Da Århus-området, som følge af store overordnede private og offentlige institutioner og en betydelig regional koncentration inden for forskning og knowhow, oplevede en vækst i den erhvervsrettede serviceproduktion, der på mange punkter lå på linje med hovedstadsmetropolens, genereredes der i 90’erne og på den anden side af årtusindeskiftet en betydelig befolkningstilvækst og -koncentration i Østjylland, der tillige tiltrak mere specialiseret industri. Visse dele af det $\varnothing$ vrige Jylland og Fyn kunne til gengæld notere en faldende befolkningstilvækst, mens Nordjylland og Lolland-Falster i samme periode fik et direkte fald i folketallet. Som helhed blev Vest-, Midt- og Sønderjylland i højere grad præget af nyere industri med relativt flere ufaglærte arbejdere og små virksomheder, mens Nordjylland og Sydhavsøerne i overvejende grad i perioden måtte afvikle hovedparten af den ældre, større og traditionelle industri. 
Tabel 9. Erhvervsbeskæftigede i hovedstadsmetropolen, 1990-2000 Index: 1990=100

\begin{tabular}{|l|c|c|}
\hline & 1990 & 2000 \\
\hline Landbrug m.m. & $100(0,9)$ & $90(0,8)$ \\
\hline Industri & $100(14,7)$ & $86(12,4)$ \\
\hline Byggeri og transport & $100(14,3)$ & $98(13,7)$ \\
\hline Handel og omsætning & $100(17,9)$ & $102(18,3)$ \\
\hline Tjenesteydende erhverv & $100(52,2)$ & $107(54,8)$ \\
\hline Hele hovedstadsmetropolen & $100[34,3]$ & $102[34,8]$ \\
\hline Hele landet & 100 & 101 \\
\hline
\end{tabular}

Kilde: Statistisk årbog for København m.v., Københavns statistiske Årbog og Statistisk Årbog, 1993 og 2001. Anm: Parentes: Den procentvise erhvervsfordeling i hovedstadsmetropolen. Kantet parentes: Hovedstadsmetropolens procentvise andel af landets beskæftigede

Den ny arbejdsdeling mellem landets egne der slog igennem i årtierne omkring årtusindeskiftet, fik således ganske betydelige demografiske konsekvenser. Mens nogle dele af landet blev mere specialiseret $\mathrm{i}$ landbrug og forskellige former for industri, og fik en svagere befolkningsudvikling, opnåede hovedstadsmetropolen, Østjyllands byer og Odense-området med en mere specialiseret industri og en udviklet erhvervsorienteret serviceproduktion en betydelig befolkningstilvækst. Danmark blev dermed efter 1990 på ny mere skævt, og tendensen tegnede til at forsætte. Befolkningsfremskrivninger i forbindelse med 2007-strukturreformen forudså således frem til 2040 en befolkningstilvækst i hovedstadsmetropolen på ikke mindre end ti procent, hvorved metropolen med en befolkning på langt over to mio. i 2040 ville opnå en andel af landets samlede befolkning på 40 procent.

En udvikling som ville have en afsmittende virkning på det øvrige Sjælland, der i endnu højere grad ville blive en del af hovedstadsmetropolen, og frem mod 2040 ville opnå en befolkningstilvækst på fire procent. Mens der i befolkningsfremskrivningerne blev forudset et fald i folketallet på ti procent i det Øvrige Jylland og på Fyn i de følgende næsten 40 år, ville det befolknings- og erhvervsmæssigt skæve Danmark kun blive modvirket af en ekspansiv erhvervsudvikling i det østjyske område, hvor fremskrivningerne frem mod 2040 opererede med en befolkningsvækst på omkring fem procent.

Tabel 10. Erhvervsbeskæftigede i hovedstadsmetropolen, 2008-2016. Index: 2008=100

\begin{tabular}{|l|c|c|}
\hline & 2008 & 2016 \\
\hline Landbrug m.m. & $100(0,5)$ & $93(0,4)$ \\
\hline Industri & $100(7,9)$ & $94(6,9)$ \\
\hline Byggeri og transport & $100(11,3)$ & $96(10,2)$ \\
\hline Handel og omsætning & $100(16,1)$ & $102(15,6)$ \\
\hline Tjenesteydende erhverv & $100(64,2)$ & $109(66,9)$ \\
\hline Hele hovedstadsmetropolen & $100(100)$ & $101(100)$ \\
\hline
\end{tabular}

Kilde:

http://www.statistikbanken.dk/statbank5a/SelectVarVal/Define.asp?MainTable=AKU200\&PLanguage=0\&PXSId=0 \& wsid=cftree 1993 og 2001. Anm.: Parentes: Den procentvise erhvervsfordeling i hovedstadsmeropolen.

Selv om hovedstadsmetropolen i forhold til det $\varnothing$ vrige Danmark gik erhvervs- og befolkningsmæssigt styrket ud af årtierne omkring årtusindeskiftet, blev udviklingen inden for selve byregionen kendetegnet af betydelige forskydninger. I de allerede fuldt udbyggede forstæder, som de nære forstæder, Vestegnen og det nordøstlige forstadsområde udgjorde, blev befolkningsudviklingen efter 1990 således mere afdæmpet, ligesom faldet $\mathrm{i}$ antal virksomheder og beskæftigede i industrien her blev mere udtalt. Nogle virksomheder bukkede under for den samfundsøkonomiske udvikling eller flyttede ud i yderamterne, til andre steder i landet eller til udlandet, og stadigt større tidligere industriområder i Gladsaxe, Herlev, Ballerup og på Vestegnen byomdannedes til nye erhvervsområder for lager- og transportvirksomhed, forskellige former for erhvervsrettet serviceproduktion og andre brancher. Det på trods blev tilvæksten i beskæftigede inden for de tjenesteydende erhverv i denne del af hovedstadsmetropolen mindre end i de $\emptyset$ vrige dele af byregionen. 
Mens disse forstadsområder således fik en svagere befolkningsudvikling, og blev præget af omstillingen fra industriforstæder til forstæder med et langt mere differentieret erhvervsliv, blev de uden for liggende byområder efter 1990 hovedstadsmetropolens ene vækstområde. I forstæderne, købstæderne og satellitbyerne i byregionens ydre dele var der friarealer til yderligere erhvervs- og boligbyggeri, og netop her blev befolkningstilvæksten stærkest i forhold til den øvrige hovedstadsmetropol. Disse yderområder kunne desuden i højere grad fastholde den hidtidige industribeskæftigelse og samtidig opvise en relativt højere vækst i beskæftigelsen inden for handel, omsætning og tjenesteydende erhverv. Med hovedstadsmetropolens gradvise erhvervs- og befolkningsmæssige udfyldning, og som følge af de relativt højere ejendomspriser i metropolen, begyndte stadig flere af dens befolkning samtidig at flytte videre ud. Efter åbningen af Øresundsbroen til Malmø-regionen i det vestlige Skåne og til tidligere Storstrøms og Vestsjællands amtskommuner, hvor der blev stadig flere pendlere fra områdets stationsbyer og navnlig fra gamle købstæder som Holbæk, Ringsted, Sorø, Slagelse og Næstved.

Tabel 11. Procentvis fordeling af erhvervsbeskæftigede i hovedstadsmetropolen 2000 og tilvækst siden 1990. Index: $1990=100$

\begin{tabular}{|l|c|c|c|c|}
\hline & Hovedstaden & Københavns Amt & Frederiksborg Amt & Roskilde Amt \\
\hline Landbrug m.m. & $160(0,1)$ & $98(0,4)$ & $84(2,0)$ & $86(2,7)$ \\
\hline Industri og håndværk & $75(8,2)$ & $87(14,9)$ & $92(15,4)$ & $98(16,1)$ \\
\hline Byggeri og transport & $88(11,9)$ & $105(16,2)$ & $92(11,6)$ & $107(14,0)$ \\
\hline Handel og omsætning & $102(15,7)$ & $103(20,5)$ & $110(19,7)$ & $111(18,2)$ \\
\hline Tjenesteydende erhverv & $110(64,1)$ & $106(48,0)$ & $107(51,3)$ & $108(49,0)$ \\
\hline Total & $99(100)$ & $102(100)$ & $102(100)$ & $105(100)$ \\
\hline
\end{tabular}

Kilde: Statistisk årbog for København m.v. og Statistisk Årbog, 1974, 1983, 1993. Anm.: Parentes: Den procentvise erhvervsfordeling i hovedstadsmetropolen.

Ifølge befolkningsfremskrivningerne for de følgende næsten 40 år ville denne trend i det store hele fortsat gøre sig gældende i det tidligere Frederiksborg Amt i den nuværende Region Hovedstaden, i hovedstadsmetropolens del af Region Sjælland og på det øvrige Sjælland. Mens fremskrivningerne forudså en stagnerende befolkningsudvikling i de indre og ældre forstæder i den tidligere Københavns Amtskommune, ville hovedstadsmetropolens andet og suverænt største vækstområde frem til 2040 være selve hovedstaden, der ifølge prognoserne ville kunne notere en befolkningstilvækst på ikke mindre end 19 procent. Den absolut højeste vækstrate for befolkningsudviklingen i hele Danmark i den estimerede 40årige periode.

Tabel 12. Hovedstadsmetropolens befolkningstal og procentvise fordeling, 1990-2011.Index: $1990=100$

\begin{tabular}{|l|c|c|}
\hline Kommune/amtskommune & 1990 & 2011 \\
\hline Hovedstaden $^{*}$ & $100(32,2)$ & $115(33,2)$ \\
\hline De nære forstæder & $100(14,8)$ & $106(14,2)$ \\
\hline Vestegnen & $100(14,2)$ & $104(13,1)$ \\
\hline Nordøst & $100(10,4)$ & $107(9,4)$ \\
\hline Nord & $100(8,7)$ & $121(9,5)$ \\
\hline Nordvest & $100(7,2)$ & $111(7,1)$ \\
\hline Vest & $100(4,9)$ & $128(5,7)$ \\
\hline Syd & $100(7,8)$ & $113(7,9)$ \\
\hline Hovedstadsmetropolen & $100(100)$ & $111(100)$ \\
\hline Hele landet & $100[33,3]$ & $108[34,4]$ \\
\hline
\end{tabular}

Kilde: Københavns statistiske Årbog, 1990. Fingerplan 2013, Miljøministeriet 2013, s. 52. Anm.: Se figur 3.* København og Frederiksberg. Almindelig parentes: Procentandel af den samlede befolkning i hovedstadsmetropolen.

Kantet parentes: Hovedstadsmetropolens procentvise andel af landets samlede befolkning. 
Uanset om disse fremskrivninger kom til at holde stik, undergik selve hovedstaden fra omkring 1990 en markant forvandlingsproces. Alene i 90'erne reduceredes industribeskæftigelsen i hovedstaden med yderligere en fjerdedel, og udviklingen fortsatte efter årtusindskiftet. Med udflytningen af Den Kongelige Porcelænsfabrik i Smallegade på Frederiksberg i 2005 og bryggeriaktiviteten på Carlsberg på det københavnske Valby tre år efter forsvandt nogle af de sidste meget store fabriksvirksomheder fra hovedstaden. Selv om hovedstaden, som følge af endnu tilbageværende fabrikker navnlig i København, i 2016 stadig omfattede en femtedel af hovedstadsmetropolens industribeskæftigede, blev flytningen af disse markante produktionsvirksomheder et symbol på den lange erhvervsmæssige transformationsproces, der havde kendetegnet hovedstaden gennem hele efterkrigstiden, og som førte til, at den udviklede sig fra et industribysamfund med traditionelle byerhverv til i 90'erne og efter årtusindskiftet at blive til et moderne servicebysamfund med service-, city-, forretnings- og styringsfunktioner for hovedstadsmetropolen og hele landet.

Selv om detailhandelen op gennem efterkrigstiden som helhed blev presset af konkurrencen fra de større enheder, havde mange af hovedstadens talrige småforretninger og navnlig specialbutikkerne på forretningsstrøgene klaret sig. I løbet af 90’erne og efter årtusindskiftet opførtes flere store forretningscentre såsom Frederiksberg Centret, Spinderiet i Valby, Nørrebro Centret, Fisketorvet og Fields. Hertil kom et større antal nye lokalcentre i de forskellige bydele, og med de forbedrede konjunkturer fra slutningen af 90'erne oplevede handel og omsætning således endnu et opsving, og endnu nye brancher kom til; såsom caféer, nye former for restauranter og spisesteder, solcentre og salgsvirksomheder inden for software og IT-udstyr.

Figur 1. Den statistiske opdeling af hovedstadsmetropolen efter 2007

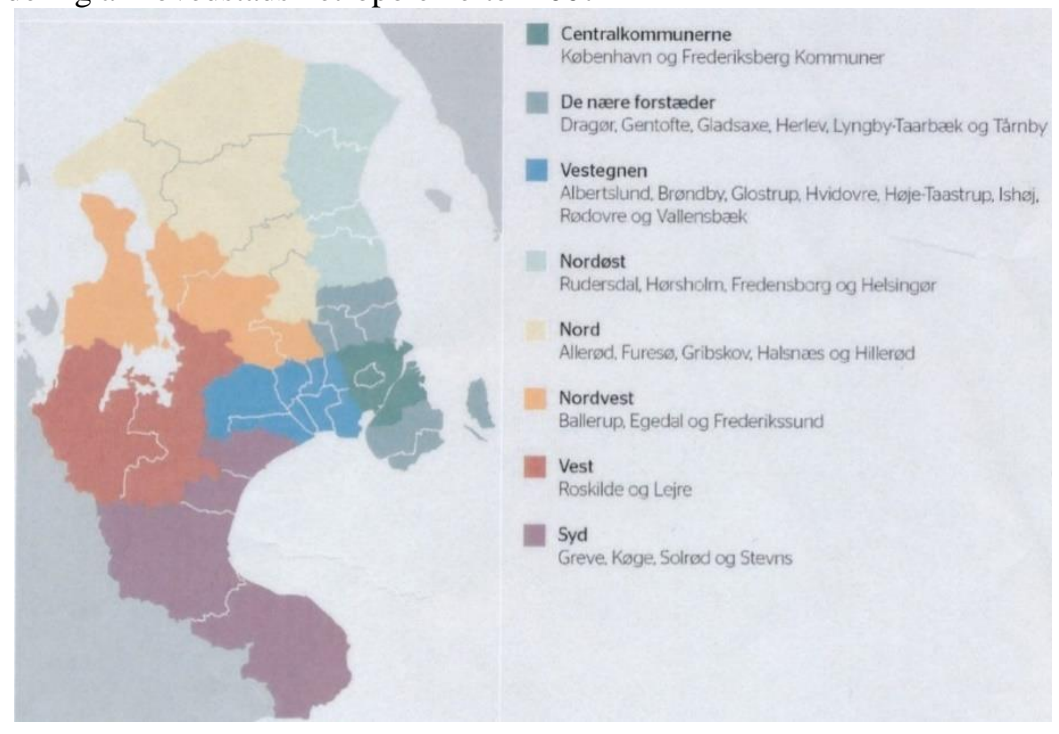

Sideløbende hermed voksede beskæftigelsen i hovedstadens øvrige tjenesteydende erhverv, der kom til at tegnede sig for over 70 procent af arbejdsstyrken i denne del af hovedstadsmetropolen. De mange statslige og kommunale arbejdspladser var en afgørende forudsætning, men væksten blev i særlig grad genereret af erhvervsrettet servicevirksomhed. Ikke mindre end en fjerdedel af landets arbejdsstyrke inden for denne branche fandt beskæftigelse i virksomheder i hovedstaden, der med den stærke koncentration af forskning og knowhow havde en særlig tiltrækning. Hermed blev der behov for nye bygningsmæssige rammer, som byomdannelserne skabte for offentlige institutioner, servicevirksomheder, administrative hovedsæder, afdelinger for store erhvervsvirksomheder og interesseorganisationer. Periodens helt nødvendige satsning på yderligere uddannelsespolitiske initiativer førte herudover til yderligere ekspansion og nybyggeri blandt mange af hovedstadens forsknings- og uddannelsesinstitutioner. Det gjaldt bl.a. Københavns Universitets 
nye komplekser, IT-universitetet på Amager og på Frederiksberg Landbohøjskolens store byggeri ud mod Rolighedsvej og talrige fakultetsbygninger for CBS.

Efter at hovedstadsmetropolens forstadskommuner i årtier havde tiltrukket en stadig større del af byregionen befolkning, blev det fra 90'erne igen "in" at bo i byen og tæt ved de mange arbejdspladser inden for de tjenesteydende erhverv. Befolkningskurven knækkede endnu engang på Frederiksberg i 1989 og i København i 1995, hvorved hovedstaden mellem 1990 og 2011 kunne dels opvise en befolkningstilvækst på 15 procent svarende til et samlet folketal på 637.000 indbyggere, dels opsuge en stigende andel af hovedstadsmetropolens befolkning. Betydelige dele af boligmassen i såvel privat som almennyttigt byggeri var efter 1970 blevet moderniseret, og helt nye, store boligområder voksede senere frem som følge af de omfattende byomdannesler. Hermed kom store dele af hovedstaden efterhånden til at rumme moderne lejligheder i både det nye byggeri og i ejendomme i de ældre og mere pittoreske bydele. En boligmasse, der, sammen med jobmulighederne i de nye tjenesteydende erhverv, vendte den negative befolkningsudvikling, og netop tiltrak de unge og yngre børnefamilier, der igen gjorde hovedstaden "yngre". ${ }^{10}$

\section{Øresundsperspektivet - en Øresundsmetropol ?}

Mens den sidste efterkrigstids stagnation og krise både i den danske hovedstadsmetropol og det vestskånske bybånd blokerede for en videre integration på tværs af Øresund, gik hele Øresundsregionen fra årtusindeskiftet ikke alene ind i en vækstperiode, men blev tillige kendetegnet af en så stærkere interaktion mellem dens forskellige dele, at regionen begyndte at udvikle sig til en interskandinavisk byregionen. Som afgørende faktorer i denne integrationsproces indgik:

Øresundsbroen, dens tilslutningsanlæg, de omfattede byomdannelser og opgraderingen af særlig kollektivtrafikken på begge sider af sundet, andre integrationsfremmende foranstaltninger og de samfundsøkonomiske strukturforandringer, som blev kentegnende for årtierne omkring årtusindeskiftet. Den nye økonomiske krise fra slutningen af $00^{\prime}$ ene lagde ganske vist en vis dæmper på integrationsprocessen i de følgende år, men i den skrivende stund syntes en række faktorer at pege i retning af en fornyet fremdrift i processen.

\section{Status \\ I forlængelse af de forbedrede konjunkturer fra slutningen af 90’erne forsatte den $\varnothing$ konomiske vækst så meget, at den i årene 2000-2006 udviste en stigning på 12 procent i Region Hovedstaden og, fra et lavere udgangspunkt, på 25 procent i Skåne. Trods en lavere vækst i Region Sjælland opnåede hele Øresundsregionen, som nu også omfattede det øvrige Sjælland og Lolland-Falster, i perioden alligevel en $\varnothing$ konomisk vækst på godt 10 procent. Væksten satte sig på samme tid bl.a. igennem i form af en vis stigning i beskæftigelsesgraden, mest i den danske del af Øresundsregionen, og i antallet af nyoprettede virksomheder i regionen. (tabel 13). Region Hovedstaden tegnede sig for det største antal nye virksomheder, Skåne for det næststørste og Region Sjælland for det mindste antal. Samlet kunne Øresundsregionen udvise en relativ højere stigning i antal nyoprettede virksomheder end i Danmark og Sverige som helhed. Antallet af nyoprettede virksomheder blev dog signifikant større i den meget ekspansive Stockholms-region end i Øresundsregionen.}


Tabel 13 .

Antalet nystartade företag per 1.000 invånare i åldern 16-64 år (2001-2009)

\begin{tabular}{|c|c|c|c|c|c|c|c|c|c|}
\hline & 2001 & 2002 & 2003 & 2004 & 2005 & 2006 & 2007 & 2008 & 2009 \\
\hline Danmark & 6,8 & 6,1 & 7,1 & 7,0 & 8,0 & 8,3 & 8,5 & 8,3 & 7 \\
\hline Sverige & 6,3 & 6,6 & 6,4 & 7,3 & 7,6 & 7,6 & 9,2 & 9,1 & 10 \\
\hline Öresundsregionen & 7,9 & 7,2 & 8,0 & 8,3 & 9,0 & 9,4 & 9,8 & 9,7 & 9 \\
\hline Öresundsregionen DK & 8,3 & 7,3 & 8,5 & 8,3 & 9,5 & 9,7 & 9,9 & 9,8 & 8 \\
\hline Region Hovedstaden & 9,3 & 8,1 & 9,4 & 9,1 & 10,2 & 10,5 & 10,6 & 10,8 & \\
\hline Region Sjælland & 6,2 & 5,7 & 6,6 & 6,7 & 7,8 & 8,3 & 8,5 & 7,7 & 6 \\
\hline Öresundsregionen SE (Skåne) & 7,0 & 7,0 & 6,8 & 8,1 & 8,2 & 8,6 & 9,5 & 9,5 & 11 \\
\hline Stockholms län & 10,6 & 10,2 & 11,2 & 11,4 & 11,1 & 13,7 & 13,8 & 13,5 & 15, \\
\hline
\end{tabular}

Kilde: http://www.orestat.se/sv/oresundsdatabasen-dansk

Med den øgede vækst og beskæftigelsesgrad kom arbejdsløshedsprocenten samtidig til at udvise en faldende tendens i Øresundsregionen (figur 2). Mest i hovedstadsmetropolen og trods den kraftige vækst i Skåne mindst i denne landsdel som følge af de paradokser, der knyttede sig til dens beskæftigelsesudvikling. Herudover generedes der i Øresundsregionen fra slutningen af 90’erne og i de følgende ti år en befolkningstilvækst, der kom til at ligger over Danmark og Sverige som helhed, og som bragte regionens samlede folketal op over 3 mio. indbyggere (tabel 14). I de fleste af årene med en kraftigere befolkningsforøgelse i Skåne end i den danske del af regionen. ${ }^{11}$

Ud over den ganske kraftige økonomiske og befolkningsmæssige vækst, der kom til at præge Øresundsregionen i det mest af 00’erne, blev samme periode tillige kendetegnet af en stærk udvidelse af interaktionen mellem dens forskellige dele. Udgjorde andelen af den svenske import, der kom fra Danmark 7 procent i 90'erne, var den i 2010 således forøget til 9 procent, mens andelen af den svenske eksport, der førtes til Danmark i samme år øgedes fra 5 til 7 procent. Samtidig forøgedes den danske import fra og eksport til Sverige fra henholdsvis 11 og 9 procent af den samlede ind- og udførsel i 90'erne til henholdsvis 13 og 14 procent i 2010. Sverige blev dermed Danmarks næstvigtigste handelspartner efter Tyskland, mens Danmark blev Sverige tredjevigtigste efter Tyskland og Norge.

Ved siden af det større handelssamkvem, der i særlig grad kom Øresundsregionen til gode, blev det meste af 00’erne kendetegnet af en kraftig stigning i antallet af flytninger på tværs af Øresund (figur 3-5). Det lavere danske renteniveau og ændringer i lånefinansieringen genererede således voldsomme stigninger i ejendomspriserne særlig i hovedstadsmetropolen, hvilket medførte, dels at nogle af metropolens virksomheder flyttede til det vestskånske bybånd, bl.a. lægemiddelvirksomhed AstraZeneca, der placeredes i Malmø og tiltrak kvalificeret arbejdskraft fra Lund, dels at antallet af personflytninger fra Sjælland til Skåne knapt tredobledes. Flytningerne fra Skåne til Sjælland næsten firedobledes ganske vist i samme periode, men i absolutte tal blev antallet af flytninger fra Sjælland til Skåne langt større. Mens 1.600 personer i 2001 årligt foretog sådanne flytninger, var antallet i $2007 \emptyset$ get til ikke mindre end 4.600. Hovedparten af disse flytninger rettede sig dog primært mod Malmø-området, hvor den danske tilflytning udgjorde henholdsvis $30 \mathrm{og} 50$ procent af Malmøs befolkningstilvækst i årene 2000-2002 og 2003-2006.

Tabel 14. Befolkningstilvækst i procent toårsperioder, 1997-2017, Øresundsregionen og øvrige Danmark og Sverige

\begin{tabular}{|l|c|c|c|c|c|c|c|c|c|c|}
\hline & $\begin{array}{c}1997- \\
1999\end{array}$ & $\begin{array}{c}1999- \\
2001\end{array}$ & $\begin{array}{c}2001- \\
2003\end{array}$ & $\begin{array}{c}2003- \\
2005\end{array}$ & $\begin{array}{c}2005- \\
2007\end{array}$ & $\begin{array}{c}2007- \\
2009\end{array}$ & $\begin{array}{c}2009- \\
2011\end{array}$ & $\begin{array}{c}2011- \\
2013\end{array}$ & $\begin{array}{c}2011- \\
2015\end{array}$ & $\begin{array}{c}2015- \\
2007\end{array}$ \\
\hline $\begin{array}{l}\text { Region } \\
\text { Hovedstaden }\end{array}$ & 1,1 & 0,9 & 0,4 & 0,2 & 0,7 & 2,1 & 2,0 & 2,1 & 2,3 & 1,9 \\
\hline Skåne & 0,6 & 1,1 & 1,4 & 1,5 & 2,5 & 2,6 & 1,7 & 1,7 & 2,2 & 3,1 \\
\hline Øresundsregionen & 0,9 & 1,0 & 0,8 & 0,8 & 1,4 & 2,3 & 1,9 & 2,0 & 2,2 & 2,6 \\
\hline Region Sjælland & 0,8 & 1,4 & 0,8 & 1,2 & 0,9 & 0,1 & $-0,1$ & 0,0 & 1,7 & 0,9 \\
\hline Øvrige Danmark & 0,4 & 0,5 & 0,5 & 0,2 & 0,9 & 0,8 & 0,2 & 0,9 & 0,9 & 1,0 \\
\hline Øvrige Sverige & 0,1 & 0,5 & 0,6 & 0,7 & 1,3 & 1,5 & 1,4 & 1,7 & 2,1 & 2,6 \\
\hline
\end{tabular}

Kilde: http://www.orestat.se/sv/oresundsdatabasen-dansk 
Med det store antal flytninger, hvor de flyttende for det mest havde arbejde og bopæl på hver sin side af Øresund, næsten seksdobledes i årene 2000-2008 det samlede antal pendlere samtidig med, at Øresundstogene i stadig større omfang benyttedes til dette rejseformål (figur 6). Mens pendlingerne fra Sjælland til Skåne i samme periode knapt firedobledes, førte den betydelige tilflytning til Skåne fra hovedstadsmetropolen til næsten en ottedobling af pendlingen fra landsdelen til metropolen (figur 7-8). Hovedparten af disse pendlere havde bopæl i det vestskånske bybånd og i særlig grad i Malmø-området, Lund og Helsingborg, mens deres arbejdssteder var koncentreret til den indre del af hovedstadsmetropolen og i et vist omfang til Helsingør (figur 9).

Blev hovedparten af 00'erne således kendetegnet af en kraftigt udvidet interaktion mellem de forskellige områder af Øresundsregionen, og som rummede realistiske muligheder for, at regionen inden for en relativ kort årrække kunne udvikle sig til en egentlig metropol, førte den krise, der slog igennem omkring 2008, den såkaldte finanskrise, til et tilbageslag for regionens vækst og integration. Både den økonomiske vækst, antallet af nyoprettede virksomheder og beskæftigelsesgraden kom til at udvise en faldende tendens, mens arbejdsløsheden på ny tog et betydeligt opsving. Med de stærkt faldende priser på fast ejendom særlig i hovedstadsmetropolen og de øvrige virkninger af krisen reduceredes antallet af årlige flytninger fra Sjælland til Skåne betragteligt, mens flytninger den modsatte vej følgelig kom til at udvise en betragtelig stigning. Som følge af det ændrede flyttemønster faldt samtidig antallet af pendlere fra Skåne til hovedstadsmetropolen dog uden at lægge sig på det lave niveau, der gjorde sig gældende ved åbningen af Øresundsbroen i år 2000. Da pendlingen fra hovedstadsmetropolen til Skåne, som følge af den tiltrækning som de højt specialiserede virksomheder særlig i Lund ydede på veluddannet dansk arbejdskraft, fortsat udviste en stigning, blev faldet i den samlede Øresundspendling langt mindre dramatisk, hvorved dette pendlingsomfang fortsat kom til at ligge langt over niveauet før åbningen af Øresundsbroen.

Figur 2.

\section{Arbejdsløse}

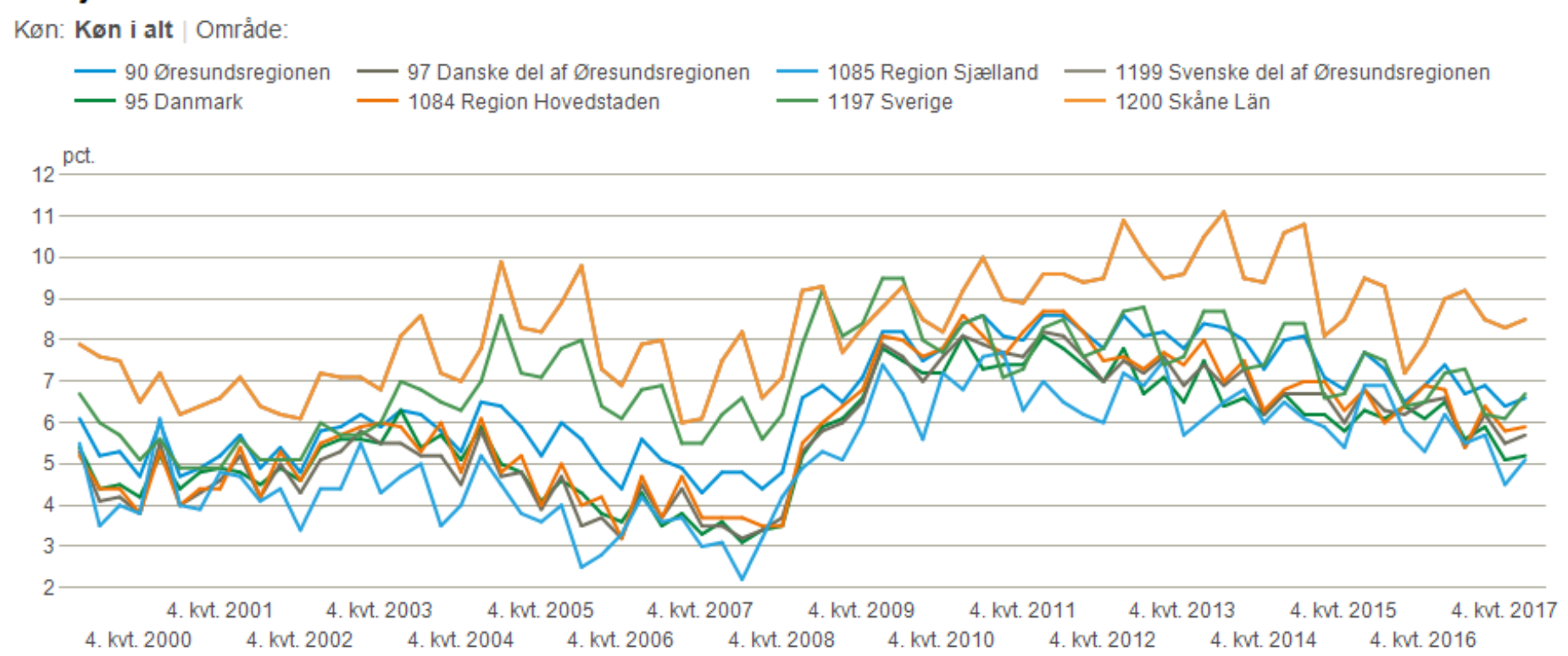

Kilde: http://www.orestat.se/sv/oresundsdatabasen-dansk

Skønt krisen ikke afgørende slog den forøgede interaktion, der var opnået i Øresundsregionen op gennem det meste af 00'erne tilbage, førte krisen til, at de danske og svenske regeringer dels blev mindre tilbøjelige til at fjerne de politisk-administrative interaktionsbarrierer mellem landene og 
dermed også i Øresundsregionen, dels ændrede de landsplanlægningsmæssige prioriteringer på bekostning af integrationen og udviklingen i Øresundsregionen. Regeringen i Stockholm prioriterede i stedet Stockholm-regionen, mens den i København på ny satte fokus på udjævning af landets regionale skævheder, bl.a. i form af udflytning af statslige arbejdspladser fra hovedstadsmetropolen til den danske provins, hvor motorveje og velfærdsstatens servicetilbud på samme tid udbyggedes.

Samtidig flyttedes en række af de internationale virksomheders skandinaviske og nordeuropæiske hovedkontorer fra Øresundsregionen til Stockholm-regionen, ligesom samarbejdet mellem Københavns og Malmø kommuner for en periode nedjusteredes. Som helhed faldt tilliden til effekten af en række af de vækst- og integrationsfremmende initiativer, der i Øresundsregionen var blevet taget siden 90’erne. En række af de organisationer og institutioner, der havde stået bag initiativerne enten droslede ned på aktiviteterne eller lukkede helt ned, hvilket bl.a. blev konsekvensen for Øresundsuniversitetet og Øresund Science Region. Med den ganske omfattende grænsekontrol der på den svenske side gennemførtes i forlængelse af flygtningetilstrømingen i 2015, blev der samtidig, i hvert fald på kortere sigt, sat meget håndfast barriere for Øresundsregionens interaktion.

\section{Figur 3.}

\section{Antal flyttningar från Sjælland till Skåne efter de flyttades medborgarskap}

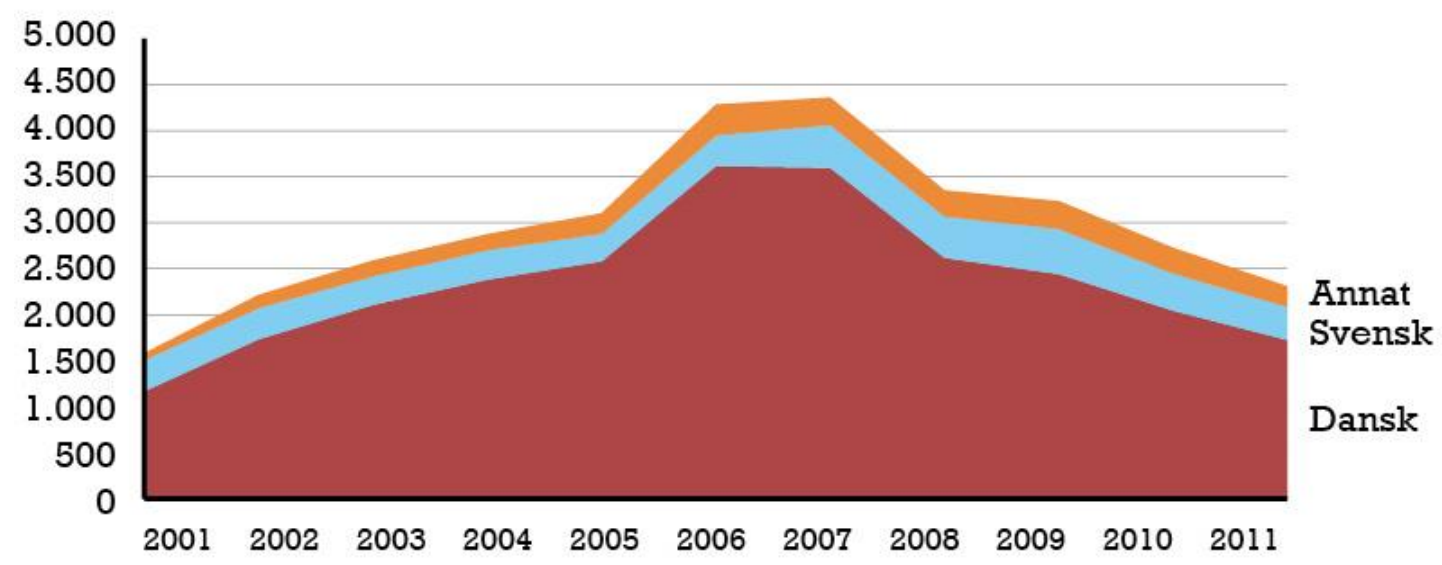

Figur 4

\section{Antal flyttningar från Skåne till Sjælland efter de flyttades medborgarskap}

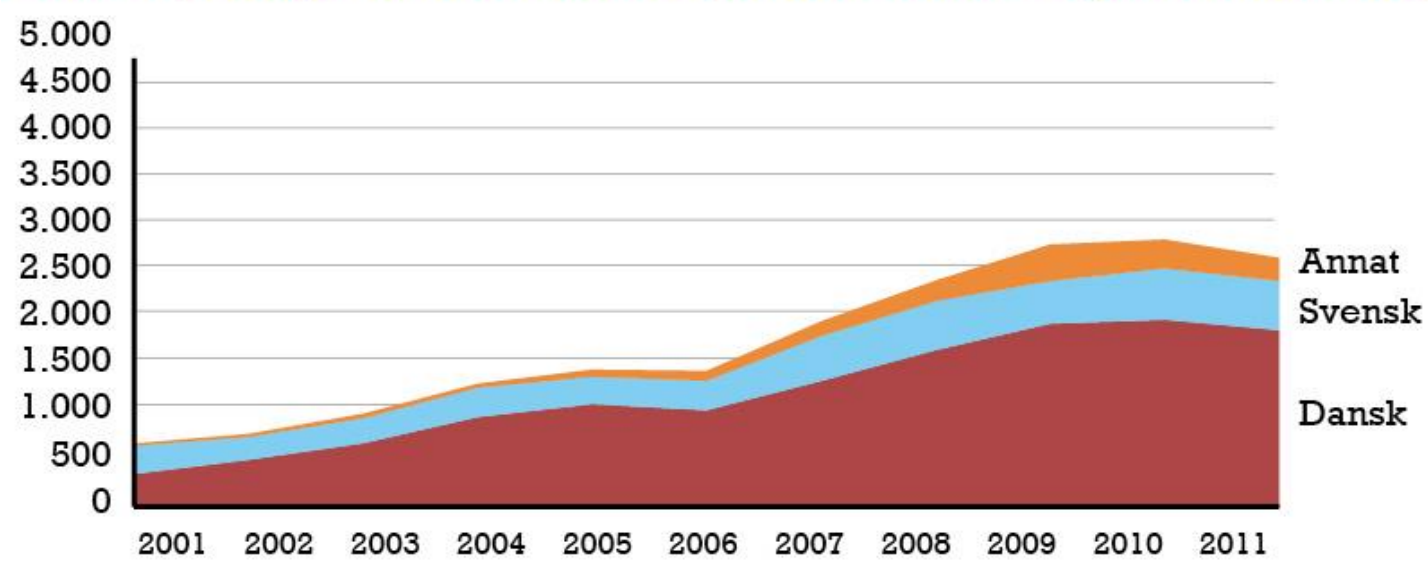

Kilde: http://www.orestat.se/sv/oresundsdatabasen-dansk 
Selv om den stagnation, der kom til at præge integrationsprocessen i Øresundregionen siden slutningen af $00^{\prime}$ erne, i lyset af den forsatte integration i store europæiske byregioner på den længere bane kunne betragte som et midlertidigt fænomen, var regionen forsat kendetegnet af en række strukturelle forhindringer for dens yderligere integration. Øresundsregionen var således stadig adskilt af to nationalstater og hver sin regionale administration, hvad deraf fulgte af svært overvindelige overordnede integrationsbarrierer, forskellige plandispositioner i hver sin del af regionen, forskellige valutaer m.m. Hertil kom, at princippet for fastsættelsen af taksterne for passage af Øresundsbroen medførte, at disse kom op på så højt et niveau, at de lagde sig i vejen for en mere gennemgribende interaktion over sundet. I 2017 udgjorde de Øresundspendlende således kun 3 og 1,3 procent af arbejdsstyrken i henholdsvis Skåne og hovedstadsmetropolen.

\section{Nye visioner og muligheder}

Trods stagnationen i Øresundsregionens integration siden slutningen af 00 'erne, levede forestillingen om en fremtidig Øresundsmetropol videre blandt en række af offentlige aktører og interesseorganisationer. Visionen om den interskandinaviske byregion udbyggedes med forestillinger om de virkninger for interaktionen i Øresundsregionen, der ville følge af: Indførelsen af euroen som betalingsmiddel både i Danmark og Sverige, en Øresundsmetro i 2030 med 4,2 mio. indbyggere og en bebyggelses- og befolkningsmæssige koncentration i hovedstadsmetropolen og det vestskånske bybånd, en fuldstændig harmonisering af reglerne for beskatning og indkomstoverførelser, en social dimension i integrationsprocessen, et fuldstændig integreret arbejdsmarked, signifikante nedsættelser af brotaksterne og en særlig politisk-administrativ autonomi i regionen.

Figur 5.

Merpriset för en familjebostad

i Region Hovedstaden jämfört

med Skåne (DKK per $\mathbf{m}^{2}$ ) samt

nettoflyttningen från Region Hoved-

staden till Skåne (1998-2011)

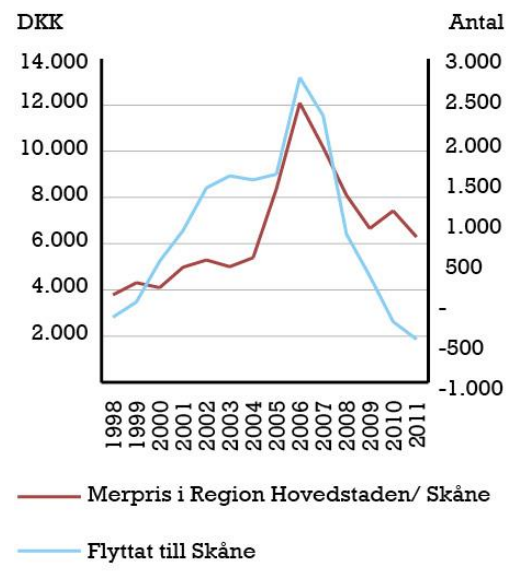

Kilde: http://www.orestat.se/sv/oresundsdatabasen-dansk

En autonomi der ville kunne opnås gennem et Øresundsparlament, et fælles Øresundsministerium, et fælles regionalt organ med mulighed for udskrivning af en særlig Øresundsskat, andre former for formelle samarbejdsorganer eller et fælles overkommunalt organ for Malmø, Lund, Københavns og Frederiksberg kommuner. Et kommunalt fællesorgan ledet af en direktion med repræsentanter for de fire kommuner med et fællessekretariat, som skulle udarbejde fælles udviklingsstrategier, afstemme kommunernes planlægning, fremme kultur og idræt og oprette selskaber for: Byudvikling og jordsalg, der skulle stå bag et Ørestad Vest ved en udbygning af Ørestaden og etablering af et Ørestad Øst ved Hylllie i Malmø, håndtering af spildevandsafledning, investeringsfremme- og 
udvikling, fremme af dannelsen af et reelt regionalt arbejdsmarked og samarbejder på miljø- og velfærdsområderne.

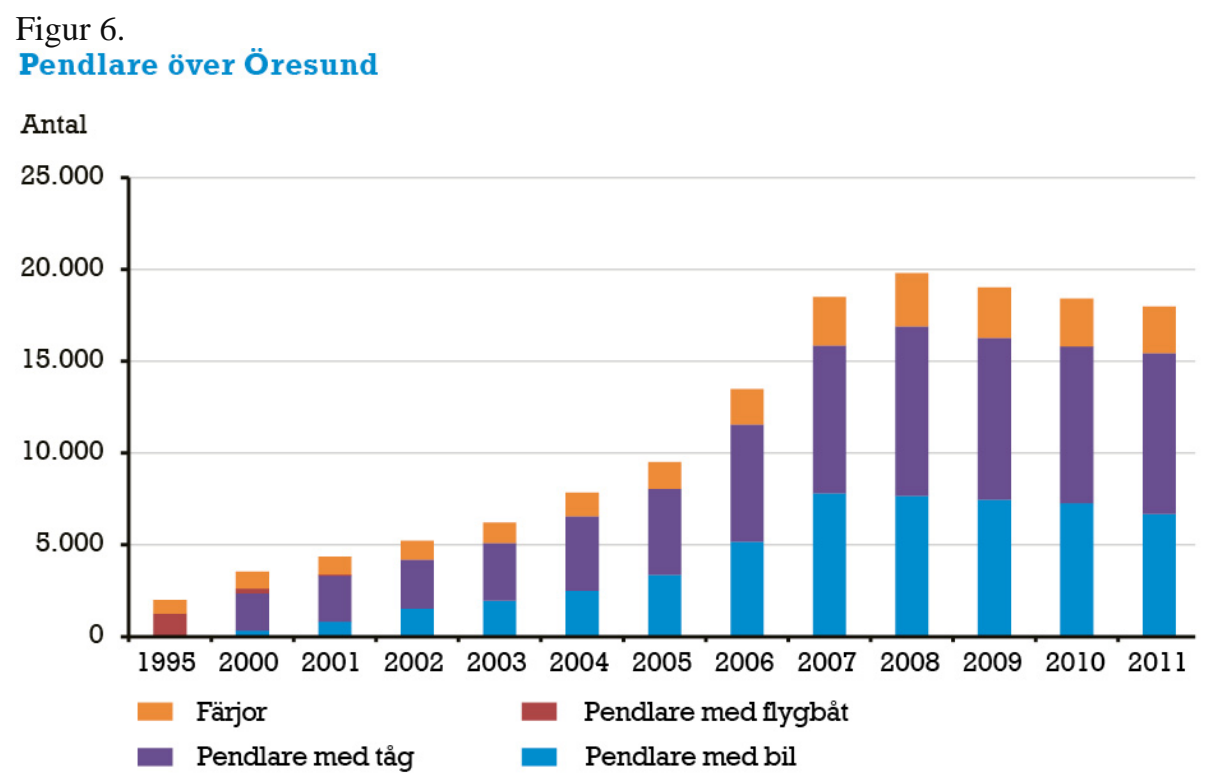

Kilde: http://www.orestat.se/sv/oresundsdatabasen-dansk

Trods disse noget vidtløftige administrative visioner for Øresundsmetropolens fremtidige styring blev det dog i første omgang kun til mindre kommunale samarbejder. Allerede i 2010 genoptog Øresundsregionens to store kommuner, København og Malmø, bestræbelser for at fremme en fortsat integration i regionen. Københavns Kommune oprettede således Copenhagen Business Task Force med henblik på en ny erhvervspolitik, der skulle gennemføres i et samarbejde med Malmø, i 2012 indledtes et nærmere plansamarbejde, som resulterede $i$, at begge byers kommuneplaner efterfølgende kom til at omfatte fælles afsnit om plandispositioner i hele Øresundsregionen, og i 2017 fremlagde de to kommuner i samarbejde med EU's Interreg-administrtation en vision for en metro mellem København og Malmø. I 2016 var Øresundskomiteen desuden blevet afløst af institutionen Greater Copenhagen, der, med en komite med repræsentanter for Øresundsregionens 79 kommunale og tre regionale myndigheder i hovedstadsmetropolen, det $\varnothing$ vrige Sjælland, LollandFalster og Skåne, skulle sætte fornyet skub i regionens integration og satse på udviklingsmulighederne for forskning, investeringer, markedsføring, digital kommunikation, et fælles arbejdsmarked i regionen og den kollektive trafik.

Netop den trafikale udbygning blev også i de nyeste, ligesom i de tidligere, visioner for Øresundsmetropolen set som helt afgørende for den skandinaviske byregion og dens forbindelser med omverdenen. Der blev således fremlagt forsalg til en fast forbindelse fra det nordlige København til Landskrona, mens det svenske statslige trafikdirektorat, Trafikverket, i 2017 lagde op til en fast forbindelse mellem Helsingborg og Helsingør i lyset af den belastning af Øresundsbroen, der ville følge af den voldsomt stigende bil- og togtrafik efter åbningen af tunnelforbindelsen under Femern Bælt i 2028. Særlig den forventede stærkt forøgede godstogstrafik på Øresundsbroen og muligheden for i højere grad at kunne anvende broen til hurtigt gående tog, bragte Øresundsmetroen spil. Som en afgrener fra en kommende ringmetrolinje på strækningen København H-Prags Boulevard- Østerport-København H, der indgik i en planlagt yderligere udvidelse af hovedstadens metro, ville Øresundsmetroen til Malmø C, med afgang hvert 1 1/2 minut 
og en hastighed på $120 \mathrm{~km} / \mathrm{t}$, reducere rejsetiden fra 35 minutter med Øresundstogene til 20 minutter og generere en vækst i den kollektive trafik over Øresund på 35 procent. Øresundsmetroen, der ud over billetindtægterne tænktes finansieret af EU-tilskud og Øresundsbroens bilafgifter, blev desuden set som en vigtig tilbringerlinje til de højhastighedstog, som, med en forventet ibrugtagning i 2035 og med 320 km/t, skulle forbinde Stockholm med København og potentielt også Hamborg.

Figur 7.

Pendlere og øvrige indkomstmodtagere fra Sverige til Danmark

Arbejdsstedskommune: 1084 Region Hovedstaden| Bopælskommune: 1200 Skåne Län

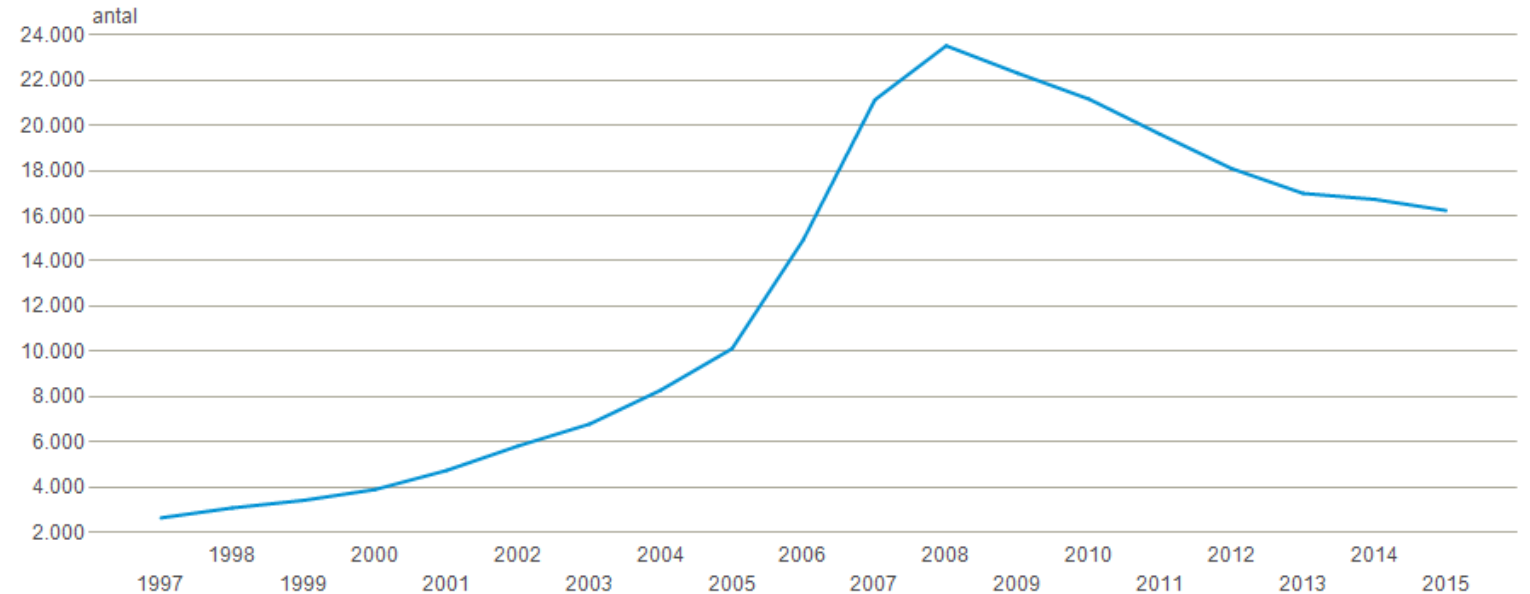

Figur 8.

Pendlere og øvrige indkomstmodtagere fra Danmark til Sverige

Arbejdsstedskommune: 1200 Skåne Län | Bopælskommune: 1084 Region Hovedstaden

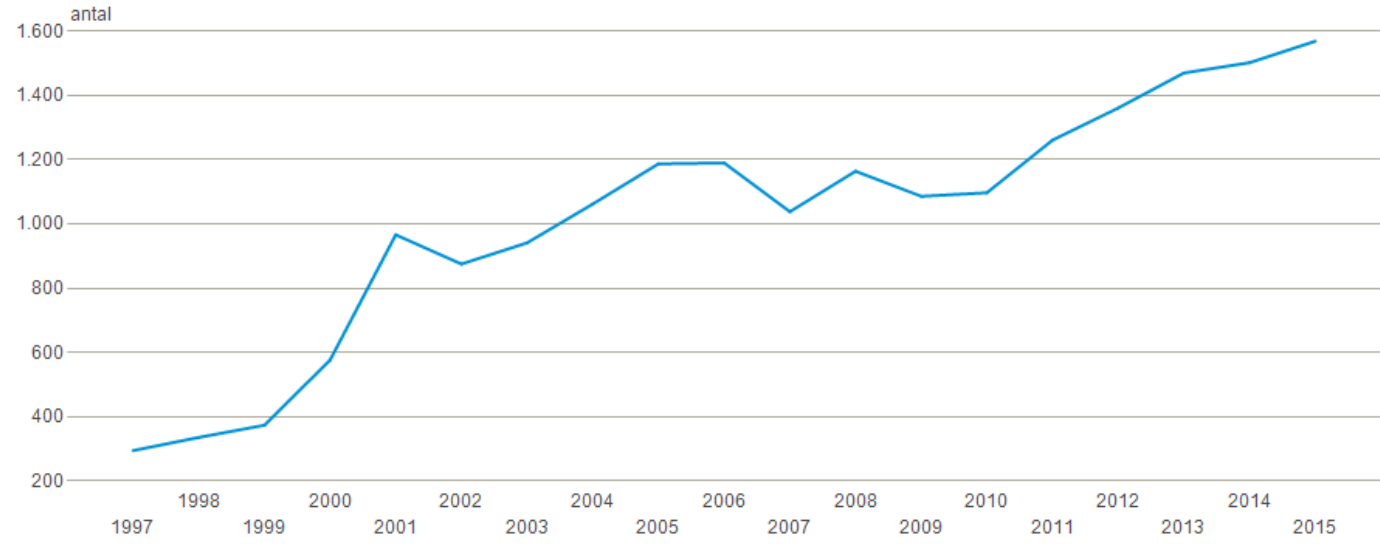

Kilde: http://www.orestat.se/sv/oresundsdatabasen-dansk

Med disse baneforbindelser ville rejsetiden fra Øresundsregionen til Hamborg og Stockholm kunne nedbringes til henholdsvis under og lidt over to timer, hvilket ville være hurtigere end flyrejsetiden inklusiv ventetider i lufthavnene til sikkerhedskontrol og bagagebehandling og rejsetiden herfra til de centrale bykerner. Som følge af den opgradering, der allerede havde fundet sted på Västkusbanen mellem Malmø og Gøteborg, i form af en dobbeltsporet højklasset jernbane med en direkte tunnelføring gennem Hallandsåsen, og med en kommende tilsvarende opgradering på strækningen Gøteborg-Oslo, ville der samtidig kunne etableres tilsvarende hurtige togforbindelser fra Øresundsregionen til disse byregioner. Trafikale rammebetingelser for at den hidtidig tænkte megaregion omfattede Øresundsregionen, Hamborg, Oslo og Gøteborg, nu kunne udvides med Stockholm. En megabyregion med over 8 mio. indbyggere, der med yderlige udbygning af det 
østlige Tysklands motorveje og højhastighedsbaner på sigt kunne omfatte Berlin-regionen. En magaregion på godt 12 mio. indbyggere, der i Europa alene ville blive overgået af London-regionen og kunne gøre sig glædede globalt, hvor man i en rimelig nær fremtid kalkulerede med megabyregioner på omkring 40 mio. indbyggere.

Siden den offentlige statistik og det politisk-administrative apparat i Danmark i mellemkrigstiden begyndte at betragte hovedstaden og de omgivende forstæder som et hovedstadsområde, en hovedstadsmetropol, og denne sammen med Skåne efter årtusindeskiftet begyndte at transformere sig til en Øresundsmetropol, var linjen lagt for, at denne op gennem det 21. århundrede skulle kunne udvikle sig til en af de store byregioner i en stadig mere interagerende og integreret megaregion omfattende hele Nordeuropa fra linjen Hamborg-Berlin i syd til linjen Oslo-Stockholm i nord.

En megaregion, der ville kunne tiltrække de massive investeringer til Nordeuropa, som ville skabe den yderlige vækst, der ville være den helt grundlæggende forudsætning for forbedrede levevilkår og sikringen og udbygningen af velfærdsstatsformen. Men vil der være politisk mod til at tilvejebringe de kollesale infrasturturinvesteringer og de gennemgribende integrationsforanstaltninger, der vil være afgørende for megaregionen ? Og vil, og i givet fald i hvor lang tid vil, den for $\emptyset$ jeblikket herskende snæversynede neonationalisme, krydret med småfacistisk fremmedfjendskhed, blokere for den yderlige politiske, økonomiske, sociale og kulturelle integration i EU, der vil være en afgørende for både den nordeuropæiske megaregionen og for, at EU-velfærdsstaten kan opstille de overordnede planmodeller og sikre både europæiske infrastrukturanlæg for trafik, forsyning og kommunikation, de nødvendige reguleringer af både samfundsøkonomiens udvikling og dens forskellige former for vildskud, i form af miljøbelastning og sociale og etnisk sekretion, samt minimunsstandarder for de enkelte nationale velfærdsstater og deres yderser og tilbud. ${ }^{12}$

Figur 9.

Pendling från den svenska sidan av Öresund till Danmark (2010)
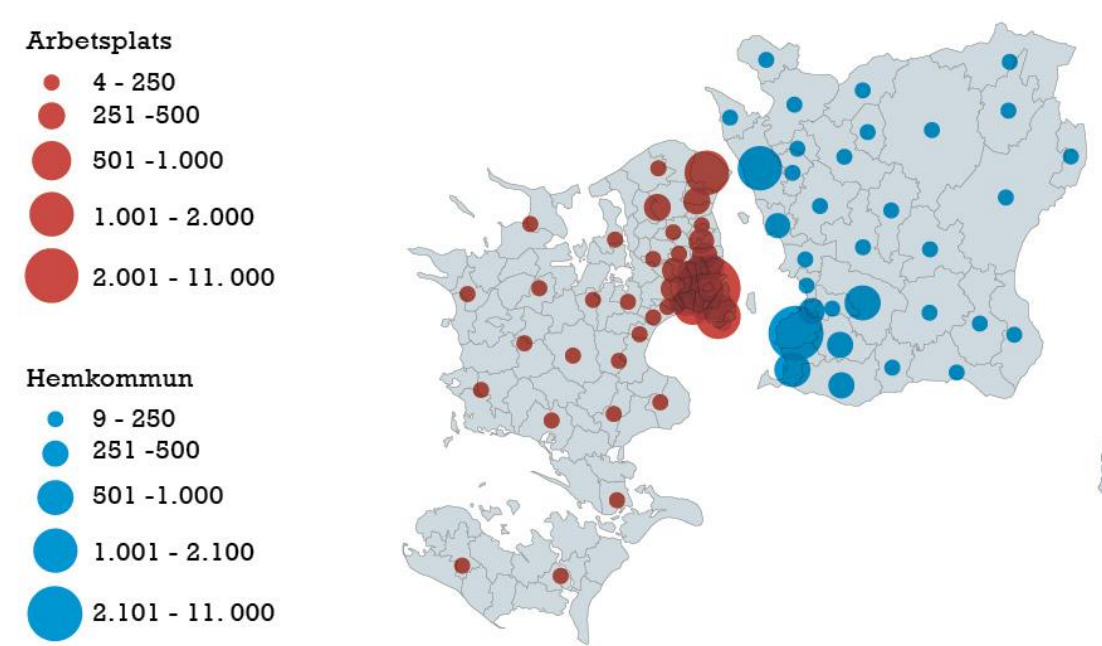

Kilde: http://www.orestat.se/sv/oresundsdatabasen-dansk

\section{Summary}

As a basis for further research into the regional history of the metropolitan area and the Øresundregion, this article focuses on how Northeast Zealand is largely developing into Denmark's most integrated region. 
The article is based on the system of Danish market towns that emerged on both sides of the Øresund during the Middle Ages, and how these interacted until the sound in 1660 formed the boundary between Denmark and Sweden. It then illustrates how Copenhagen further strengthened its position as Denmark's largest and dominant city during the absolutism in the rest of the 17th century, up through the following and in the first half of the 19th century at the same time as Skåne became a peripheral region in Sweden.

Then the article focuses on how the capital with the urbanization of industrialization expanded in the latter half of the 19th century and subsequently in the 20th century became the center of the metropolitan metropolis that, with suburbs and cities in the uplands, reached more than 1.7 million inhabitants. During the same period, this urbanization process characterized the interconnected cities on the west coast of Skåne, and is seen as a prerequisite for Øresund's cities to develop into an inter-Scandinavian urban region after the opening of the Øresund Bridge in 2000.

\section{Litteratur:}

Bach, Micahel, Henning Bro og Helga Mohr: Gennem veje og alleer på Frederiksberg, 2005. Bro, Henning og Michael Bach: Ude på Frederiksberg, 2001.

Bro, Henning og Helga Mohr: Frederiksberg Kommune 1858-2008, 2008.

Bro: Øresundsmetropolen, Historien om den interskandinaviske byregion, 2019.

Bro, Henning: Metropoludfordringer. Byregionale udfordringer og løsninger i den danske hovedstadsmetropol 1850-1990, 2019. [Disputats antaget til endelig bedømmelse af bedømmelsesudvalg, Aarhus Universitet].

Den klassiske købstad, Danske bystudier 2 (red. Søren Bitsch Christensen), Aarhus

Universitetsforlag og Dansk Center for Byhistorie, 2005.

Københavns Amt. Kulturhistoriske oversigt. Nyere tid 1336-1997, Københavns Amtskommune, 1999.

Matthiesen, Christian Wichmann. Byernes roller i Bysystemt - et global perspektiv, 2016 i Den faste Femern Bælt-forbindelse, 2016.

Middelalderbyen. Danske bystudier 1 (red. Søren Bitsch Christensen), Aarhus Universitetsforlag og Dansk Center for Byhistorie.

Olshov, Anders: Øresundsregionen. Københavns uudnyttede mulighed, 2013.

Trap: Danmark, 5. udg., Storkøbenhavns III, bd. II, 2 og II, 3, 1960.

Wetterberg, Gunner: Skånes historia, bd 3: 1720-2016, 2017.

Øresundsmetro. København. Malmø, Malmø Stads, Københavns Kommune og EU Interreg, 2017. http://www.orestat.se/sv/oresundsdatabasen-dansk www.byhistorie.dk/den-klassiske-periodewww.byhistorie.dk/vikingetid-og -middelalder.

\section{Noter:}

${ }^{1}$ En primatby er den førende by i et land eller en region. Begrebet blev fastlagt af den amerikanske geograf Mark Jefferson (18641949), der definerede en primatby som en by, der er mindst dobbelt så stor som den næststørste by.

${ }^{2}$ Trap: Danmark, 5. udg., Storkøbenhavns III, bd. II, 2, s.828-883. www.byhistorie.dk/den-klassiske-

periodewww.byhistorie.dk/vikingetid-og -middelalder. Byernes udvikling behandles nærmere i: Søren Bitsch Christensen: De danske middelalderbyers fremkomst, udvikling og udforskning i Middelalderbyen. Danske bystudier 1 (red. Søren Bitsch Christensen), Aarhus Universitetsforlag og Dansk Center for Byhistorie, 2004 og Den klassiske købstad, . Danske bystudier 2 (red. Søren Bitsch Christensen), Aarhus Universitetsforlag og Dansk Center for Byhistorie, 2005.

${ }^{3}$ Københavns Amt. Kulturhistoriske oversigt. Nyere tid 1336-1997, Københavns Amtskommune, 1999, s. 11-19, 34-37, 211-213, 296-297, 342-352. Trap: Danmark, 5. udg., bd. II,3, 1960 s. 935-1014 og bd. III, 1, 1953, s. 96-266. Henning Bro og Michael Bach: Ude på Frederiksberg, 2001, s. 11-40. Henning Bro og Helga Mohr: Frederiksberg Kommune 1858-2008, 2008, s. 9-21. Michael Bach, Henning Bro og Helga Mohr: Gennem vejeog alleer på Frederiksberg, 2005, s. 134-135.

${ }^{4}$ Henning Bro: Metropoludfordringer. Byregionale udfordringer og løsninger i den danske hovedstadsmetropol 1850-1990, 2019.

[Disputats antaget til endelig bedømmelse af bedømmelsesudvalg, Aarhus Universitet], s. 70-88. 
${ }^{5}$ Bro: Metropoludfordringer, 2019, s. 89-123.

${ }^{6}$ Bro: Metropoludfordringer, 2019, s. 124-130 og 135-183.

7 Bro: Metropoludfordringer, 2019, s. 130-183.

${ }^{8}$ Direkte inspireret Storbritanniens konservative premierminister Thatchers opløsning af det Labour-styrede metropolråd i 1985 i London-metropolen, nedlagde den sidende danske konservativt ledede regering i 1989 i et helt tilsvarende ideologisk opg $\varnothing r$ Hovedstadståret, som man anså som et socialdemokratisk centralistisk organ. De centrale regionsopgaver gled for en periode tilbage til de to hovedstadskommuners og de tre hovedstadsamtskommunersenkeltvise løsning, og kun Hovedstadsormådet Trakfikselskab forsatte som en regionlt dækkende offentlig virksomhed. Selv om hovedstadskommunerne- og amtskommunerne var forpligtet til at følge linjen i Hovedstadsrådet Regionsplan 1989, begyndte de i højere at miste ejerskabet til regionsplanen og agerede stadig mere autonomt i forhold til egne interesser og dermed uden hensyn til hele hovedstadsmetrpolen overordnede regionale planmæssige hensyn. Netop dette forhold var afgørende for, at den socialdemokartisk ledede regering i år 2000 på ny etbalerede et regionalt organ, HUR, over hovedstadsmetrpolen 3 amtskommuner, to hovedstadskummuner og store antal primærkommuner. Med 2007-

strukturreformen, hvorved amtskommunerne nedlagdes og deres opgaver overførtes til staten, regioner og de nye storkommuner, blev HUR opgaver overført til Region Hovedstaden. Som følge af en studehandel med daværende indenrigsminister Lars Løkke Rasmussen og Roskilde Amtskommunes tidligere amtsborgmester Kristian Ebbensgård, begge fra Venstre, blev denne amtskommunes område tillagt Region Sjælland, hvorved den med den $\varnothing$ vrige hovedstadsmetropol stærkt integrede amtskommunes regionaladminsitrative opgaver kom til at ligge uden for Regions Hovedstadens myndighedsområde.

${ }_{9}^{9}$ Med udgangspunkt i Hovedstadsrådets Regionsplan 1989 kunne HUR fremlægge Regionsplan 2005, der opretholdt hovedstrukturen, knudepunkts- og stationsnærhedsprincippet fra den 16 år gamle plan og ellers lagde op til yderligere forlængelser af forstadsbåndene til områderne vest for Roskilde og syd for Køge og en noget større byvækst ude i de ydre dele af

hovedstadsmetropolen. En trafikal integration med Skåne og en videreudvikling af rekreative områder fik tillige en central placering $\mathrm{i}$ Regionsplan 2005, og udmøntedes dels i en samlet plan for overordnede og regionale vej- og baneanlæg på begge sider af Øresund, dels i forlængelser af de rekreative grønne kiler i takt med forstadsbåndenes forlængelse og et ydre grønt bælte længere ud om det hidtidige grønne bælte, som Stor Vejleådalen og det nord herfor liggende koncentriske rekreative område udgjorde. Med 2007strukturreformen og dens administrative opsplitning af hovedstadsmetropolen blev det Miljøministeriets opgave at udarbejde regionsplandirektiver for hele byregionen. Et arbejde, der resulterede i dirktiver fra 2007, 2013 og 2017, som i det væsentligste byggede videre på HUR's regionsplan 2005, men som noget nyt omfattede betydelige udvidelser af de rekreative områder i hovedstadsmetropolens ydre dele og en genoplivning af den gamle transportkorridor mellem Nordsjælland og Køge fra Regionsplan 1973, dog uden de dertil knyttede bolig- og erhvervsområder.

${ }^{10}$ Afsnittet bygger på: Bro: Metropoludfordringer, 2018. s. 1190-1208.

${ }^{11}$ I peiroden mellem 1997 og 2017 øgedes Region Hovedstadens folketal fra 1,6 til 1,8 mio. og Skånes fra 1,1 til 1,3 mio. Den samlede indre Øresundsregions befolkning øgedes såldes i samme periode fra 2,7 til 3,1 mio. indbyggere. Tillagdes Region Sjællands, der henregnedes til Greater Copenhagen, befolkningstal, der i perioden $\emptyset$ gedes fra 778.000 til 835.000, forøgedes den udvidede Øresundsregions befolkning fra 3,5 til knapt 4 mio. I perioden forøgedes det $\varnothing v$ vrige folketallet i Danmark og Sverige udenfor Greater Copenhagen sig i perioden fra henholdvis 2,9 mio. og 7,7 mio. til 3,1 og 8,7 mio. indbyggere.

${ }^{12}$ Afsnittet bygger på: Gunner Wetterberg: Skånes historia, bd 3: 1720-2016, 2017, s. 626-628. Anders Olshov: Øresundsregionen. Københavns uudnyttede mulighed, 2013, s. 9-10, 16-36, 38-70, 166-167. Christian Wichmann Matthiesen. Byernes roller i Bysystemt - et global perspektiv, 2016 i Den faste Femern Bælt-forbindelse, 2016, s. 114-145. Øresundsmetro. København. Malmø, Malmø Stads, Københavns Kommune og EU Interreg, 2017. Afsnittets figurer og tabeller bygger, hvor andet ikke er angivet, på http://www.orestat.se/sv/oresundsdatabasen-dansk 